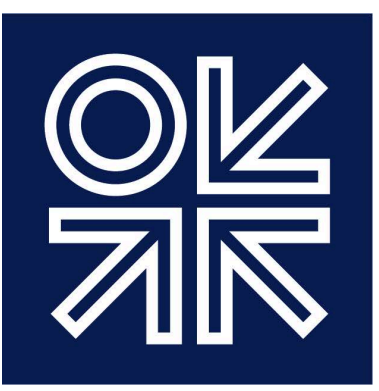

THE OXFORD INSTITUTE FOR ENERGY STUDIES

January 2014

\title{
A Roadmap for Renewable Energy in the Middle East and North Africa
}

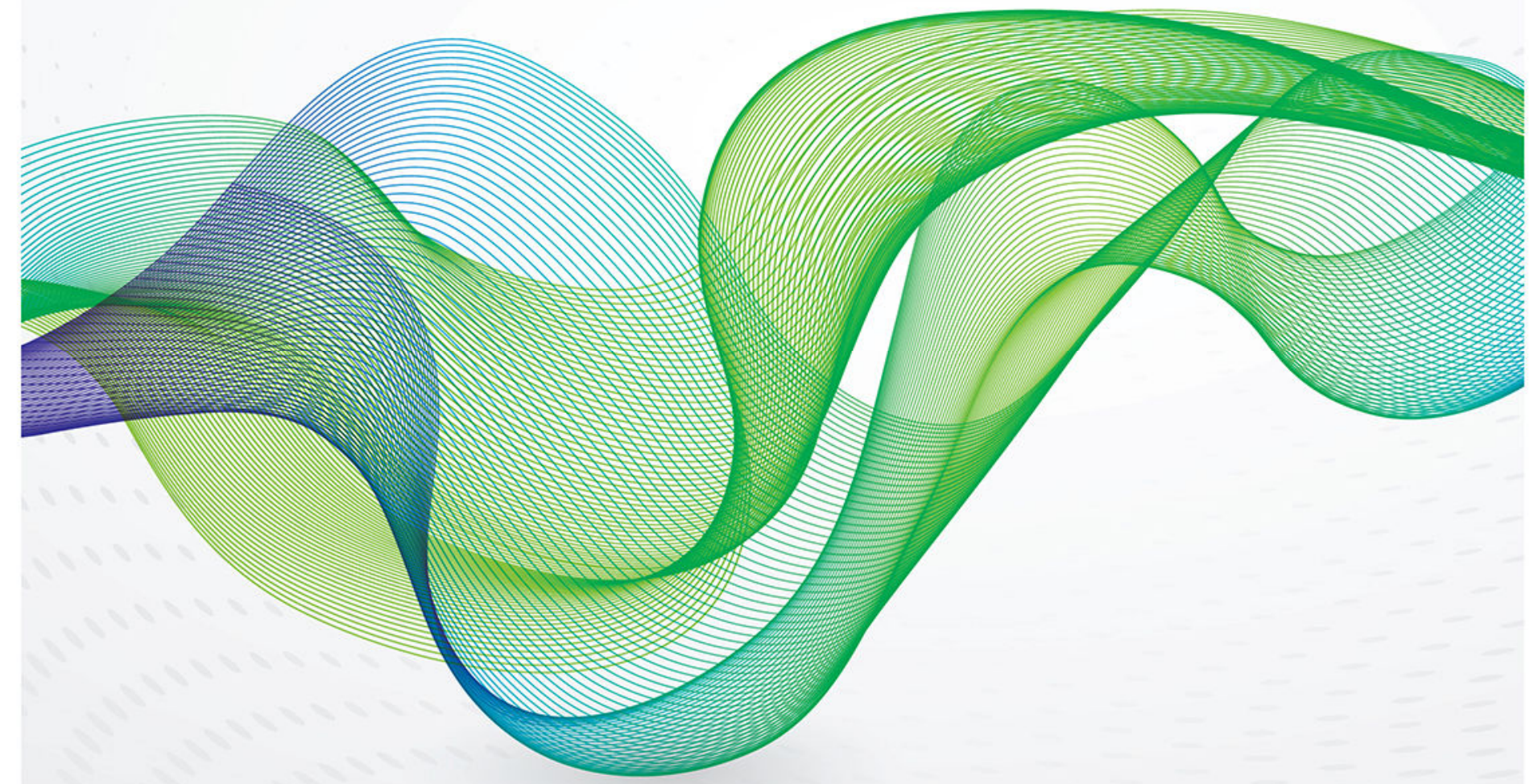

Laura El-Katiri 
The contents of this paper are the authors' sole responsibility. They do not necessarily represent the views of the Oxford Institute for Energy Studies or any of its members.

\section{Copyright $\odot 2014$}

Oxford Institute for Energy Studies

(Registered Charity, No. 286084)

This publication may be reproduced in part for educational or non-profit purposes without special permission from the copyright holder, provided acknowledgment of the source is made. No use of this publication may be made for resale or for any other commercial purpose whatsoever without prior permission in writing from the Oxford Institute for Energy Studies.

ISBN 978-1-907555-90-9 


\begin{abstract}
Home to more than half of the world's crude oil and more than a third of its natural gas reserves, the MENA region has, for the past fifty years, gained enormous significance as a global producer and exporter of energy. The MENA region is already a major energy consumer, and is forecast to continue to account, alongside Asia, for the majority of the world's energy demand growth well into the 2030s; placing domestic energy policies at the heart of the region's economic agendas for the coming decades. This paper argues that renewable energy - most importantly solar power, with its particular regional climatic advantage - could play a significant role as a cost-competitive alternative to conventional fossil fuels, if the full opportunity cost of domestically consumed oil and natural gas resources is fully priced into the regional energy system. The absence of cost-reflective energy and electricity tariffs in the MENA region today currently conceals this potential cost advantage; and leaves renewable energy deployment subject to further, economically distorting, policies such as renewables targets and fiscal incentives. Systematically opening up the economic opportunities offered by renewable energy to the MENA region will hence require structural reform of regional energy market and pricing mechanisms, thereby rationalizing the use of different energy sources in each domestic market.
\end{abstract}




\section{Acknowledgements}

The author would like to express her special thanks to Bassam Fattouh, Robin Mills, David Robinson, Malcolm Keay, Mari Luomi, and Abdulrahman Al-Ghabban for their helpful comments on earlier drafts of this paper. Many thanks also to the Arab Union of Electricity Producers for kindly providing some of the underlying data for this research; and the Israeli Public Utility Authority for providing data on Israel and the Palestinian Territories. All remaining errors are the sole responsibility of the author. 


\section{Contents}

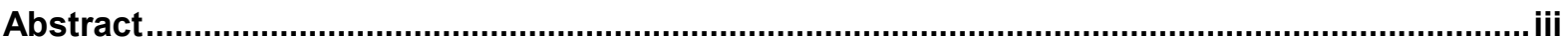

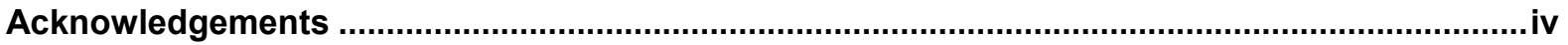

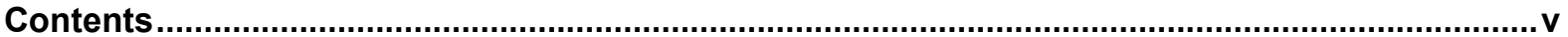

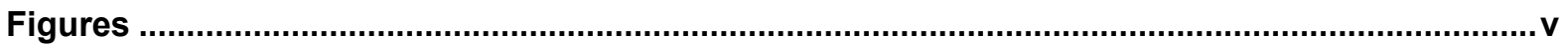

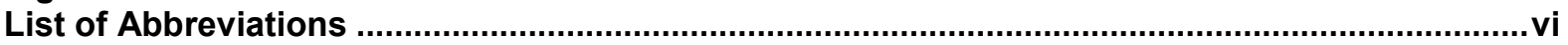

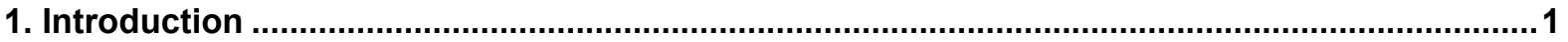

2. The MENA Region's Changing Energy Landscape .............................................................

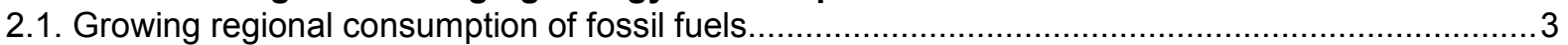

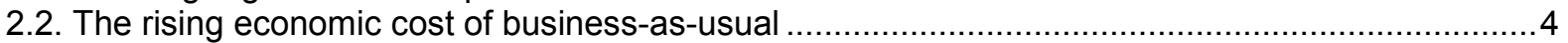

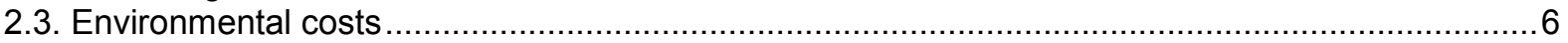

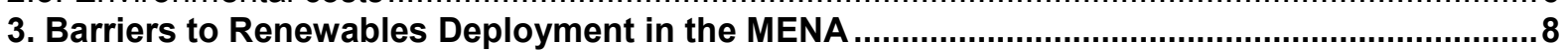

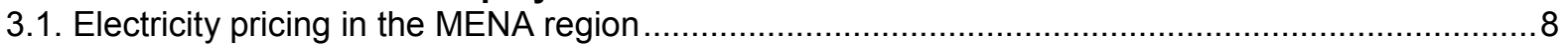

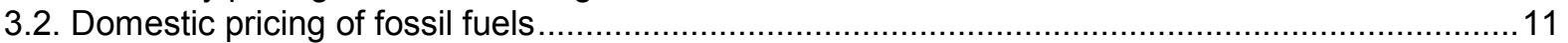

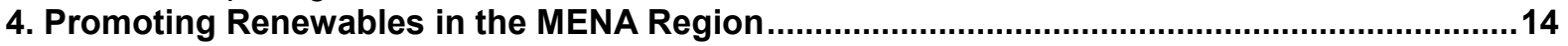

4.1. The economics of the first best: market incentives ........................................................... 14

Energy market liberalization (i): Reforming domestic energy prices.......................................... 14

Energy market liberalization (ii): Bringing in the private sector ................................................ 15

4.2. The economics of the second best: fiscal and regulatory incentives ........................................16

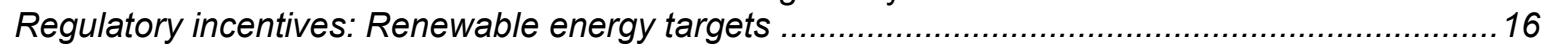

Fiscal incentives: carbon taxes, tax benefits, feed-in tariffs.................................................... 18

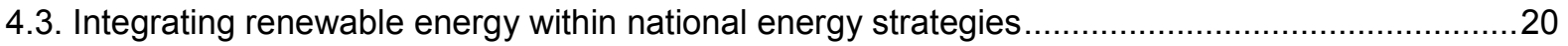

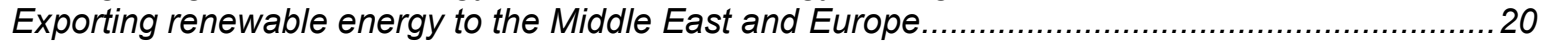

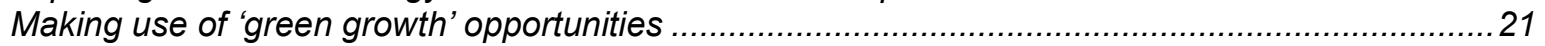

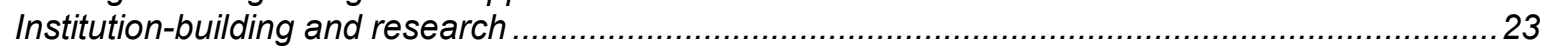

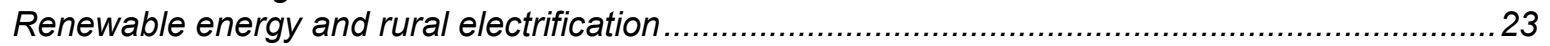

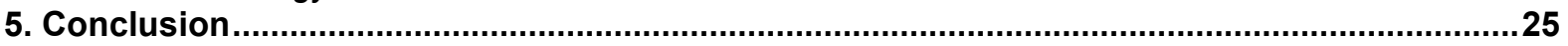

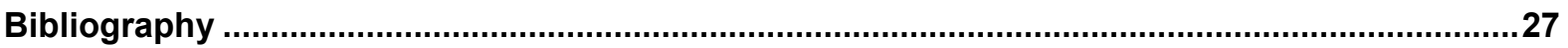

Appendix I: Basic Considerations when Estimating the Cost of Renewable Energy in the MENA

High initial capital costs

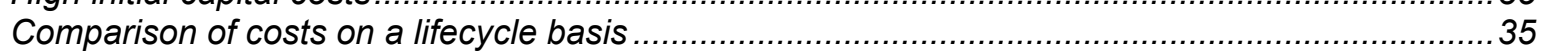

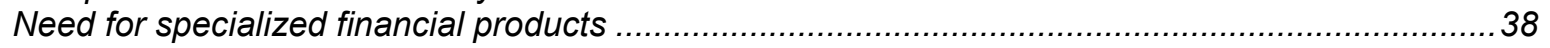

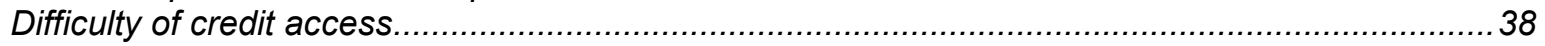

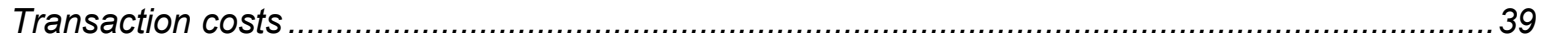

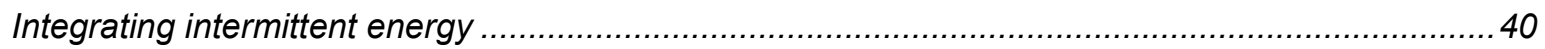

Positive and negative externalities: costs unaccounted for ..................................................... 40

Appendix II: Renewable Technologies and their Application in the MENA .................................43

\section{Figures}

Figure 1: Regional Trends in Energy Use, Compound Average Annual Growth, 1971-2010 .............3

Figure 2: Regional Trend in Energy Intensity, Compound Average Annual Growth in Energy Use,

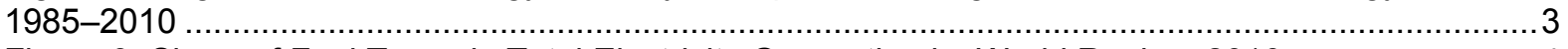

Figure 3: Share of Fuel Types in Total Electricity Generation by World Region, 2010 .......................4

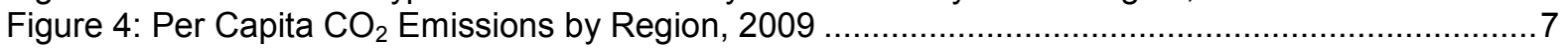

Figure 5: Regional Trend in $\mathrm{CO}_{2}$ Emissions Growth, 1980-2009* ..........................................

Figure 6: Cross-Country Comparison of Average Residential Electricity Prices in Selected MENA and

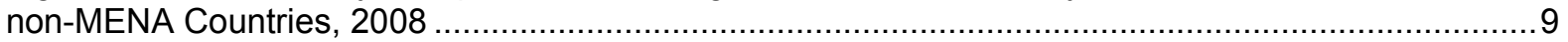

Figure 7: Residential, Commercial, and Industrial Electricity Prices in Selected MENA Countries, 2012

Figure 8: Trends in Renewable Energy Investment in the MENA Region, 2009-2012......................... 18 


\section{List of Abbreviations}

$\mathrm{CO}_{2}$

CSP

ECRA

EIA

ESIA

FIT

GCC

GDP

IEA

IRENA

LCOE

LRMC

MENA

NEC

NIC

OECD

OPEC

PERG

PV

RES

UAE

UNFCCC

US $\phi$

US\$
Carbon Dioxide

Concentrated Solar Power

Saudi Arabia's Electricity and Co-generation Regulatory Authority

U.S. Energy Information Administration

Emirates Solar Industry Association

Feed-in tariff

Gulf Cooperation Council

Gross Domestic Product

International Energy Agency

International Renewable Energy Agency

Levelized Cost of Energy

Long-Run Marginal Cost

Middle East and North Africa

Net Energy Exporting Countries

Net Energy Importing Countries

Organisation for Economic Cooperation and Development

Organization of Petroleum Exporting Countries

Programme d'Électrification Rurale Global

(Solar) Photovoltaic

Renewable Energy Sources

United Arab Emirates

United Nations Framework Convention on Climate Change

US Dollar Cent

US Dollar 


\section{Introduction}

'The sun will be the fuel of the future' Anonymous, 1876, Popular Science ${ }^{1}$

The Middle East and North Africa (MENA) has, for most of its modern-day history, been known for its energy wealth. ${ }^{2}$ Home to more than half of the world's proven crude oil and more than a third of its natural gas reserves, the dominant story of the MENA region has for the past fifty years been that of a global energy supplier. ${ }^{3}$ Consequently, the MENA region's domestic energy market has been seen for decades as marginal in the global picture, supplied with amply available, regionally produced, lowcost fossil fuels. With some of the world's lowest domestic prices for both primary energy and electricity, the MENA region has appeared to lack the kind of economic incentive needed for alternative energy sources, such as renewable energy and nuclear power, to enter its markets.

The perceived abundance of low-cost energy supplied by fossil fuels has undoubtedly fuelled the region's domestic energy demand growth, having spurred both extensive energy-intensive industrialization programmes and the rapid rise in living standards experienced by some of the region's oil exporters - in particular the economies of the Gulf Cooperation Council (GCC). Forecast to stand alongside Asia in accounting for the majority of incremental global primary energy demand growth well into the 2030s, the MENA region is a rapidly growing energy consumer. ${ }^{4}$ But the rise in regional energy consumption comes at considerable economic cost: rising prices for oil on world markets since the early 2000s have raised the cost of imported oil and oil products for MENA net energy importing countries (NICs), while many oil and gas producers (net energy exporting countries, or NECs) divert growing shares of their oil and natural gas production away from high-price international markets, to supply domestic demand at growing opportunity cost. ${ }^{5}$

In this paper, we argue that renewable energy options such as wind and solar energy, overlooked for decades owing to missing commercial incentives, could offer the region a valuable energy alternative to fossil fuels in power generation. This would save MENA economies not only rising import costs for oil in electricity use, but also free valuable crude oil resources for export by the region's hydrocarbon producers. The MENA region's almost unrivalled climatic advantages (particularly in solar energy ${ }^{6}$ ), together with its high level of reliance on oil for power generation, may indeed render some renewable energy technologies cost-competitive to conventional fossil fuels, provided the full opportunity cost of alternative fuels is taken into account. Under these assumptions, the MENA region could indeed do without the type of renewable energy subsidies needed in other, more developed, renewable energy markets in order to incentivize market uptake. The case is considerably stronger for renewables substituting for oil than for natural gas, although the price advantage of renewables over gas rises

\footnotetext{
1 Quoted in IEA (2011c, 4).

2 In this paper, the Middle East and North Africa region includes Algeria, Bahrain, Egypt, Iran, Iraq, Israel, Jordan, Kuwait, Lebanon, Libya, Morocco, Oman, Palestine (where data is available), Qatar, Saudi Arabia, Syria, Tunisia, United Arab Emirates (UAE), and Yemen. Regional data for the MENA region based on World Bank aggregates include Malta and Djibouti unless otherwise stated.

3 Data as of end-2012, BP (2013).

4 E.g. IEA $(2012 b, 57)$.

5 Some simulations of Saudi Arabia's domestic oil demand, for instance, such as those conducted by Chatham House and Citibank, show the potential for Saudi Arabia under a business-as-usual scenario to exhaust its own domestic reserve base in just 15 to 20 years, turning itself ultimately into a net importer of oil unless alternative policy options are pursued. Lahn and Stevens (2011); Bloomberg (2012).

6 Reasons include the MENA region's overall high level of insulation, coupled with high irradiation levels and land availability, as well as statistically many sun hours per year, and reliably low precipitation risk during the summer months, particularly on the Arabian Peninsula. Morocco is also believed to host some of the best wind sites in the world. DLR (2005); OECD (2013); IRENA (2013b). Separate studies are available for a variety of MENA countries, including Egypt, Morocco, Algeria, Iraq, Iran, and Saudi Arabia. See Karakosta and Psarras (2013); Stambouli (2011); Vidican (2012); Razavi (2012); Pejat et al. (2013); Dehghan (2011); Kazem and Chaichan (2012); Al-Saleh et al. (2008); Saudi Arabia Solar Industry Association (2013).
} 
along with a higher share of non-pipeline gas imports. Raising the share of renewable energy in the MENA region would also result in significant environmental, and thereby wider social, benefits although current pricing mechanisms inside and outside MENA countries do not yet reflect these benefits as part of the pricing of renewables-based energy generation - they hence remain a positive externality, rather than a factor driving down costs.

Key to understanding - and fully exploring - the potential economic value of key renewable energy technologies, however, requires a reconsideration of the MENA region's domestic pricing frameworks, and a restructuring of regional energy markets to free up the cost advantages that renewable energy sources may provide. Current tariff systems do not reflect economic costs - such as the import cost paid via budgetary transfers rather than by utilities or final consumers (energy subsidies) - or the opportunity cost incurred by producers. The absence of cost-reflective energy and electricity tariffs in the MENA region today currently conceals this potential cost advantage, leaving renewable energy deployment subject to further economically distorting policies such as pre-determined renewables targets and vague notions of 'green' job creation opportunities.

In order to make use of the real economic opportunities potentially offered by renewable energy, the MENA region will require a structural reform of domestic energy market pricing. This, however, could take the form of an alternative policy framework that encourages the deployment of renewables via fiscal and regulatory incentives. Other incentives may include the exploitation of positive externalities of renewables in the regional context - by using solar and wind technologies for rural electrification projects, displacing expensive fuels such as diesel, and exporting electricity abroad. However, caution must be applied to expectations that see renewable energy as a saviour-for-all, for example, that it could be a driver for local manufacturing industries and 'green job' creation. The paper proceeds as follows:

- $\quad$ Section 2 introduces the context for the MENA region's changing energy landscape that may create an economic opportunity for renewable energy on a cost-competitive basis;

- $\quad$ Section 3 examines those factors that have so far prevented a greater share of renewable energy sources (RES) deployment in the MENA region, principally energy pricing; and

- $\quad$ Section 4 suggests policy options which the MENA economies could follow to capitalize on their renewable energy resources.

- $\quad$ Section 5 presents the conclusions.

\section{The MENA Region's Changing Energy Landscape}

The MENA region's domestic energy landscape has undergone tremendous change throughout the region's modern-day history. This section summarizes the main factors that account for the region's shift from being a mere producer to becoming a main demand growth market for energy, together with the economic reasons why MENA economies would reasonably want to consider renewable energy sources, in light of the region's historical, overwhelming reliance on fossil fuels and its presumable cost advantage in these energy sources. We suggest two main factors that have played a significant role in shifting regional energy priorities:

(i) the surge in regional energy demand across MENA economies, and its implication on the export capacity of the region's producing countries; and

(ii) the rising economic cost of surging domestic energy demand in both net energy exporting countries (NECs) and net energy importing countries (NICs) as a result of rising oil prices since the early 2000s and the region's continued reliance on oil for a large share of its domestic energy supply.

We also discuss a third, related aspect, one whose economic weight is less easily quantifiable:

(iii) the environmental consequences of continued use of fossil fuels for virtually all of the region's energy needs. 


\subsection{Growing regional consumption of fossil fuels}

The MENA region has historically been a peripheral demand market for energy; the consequence of its initially low levels of industrialization (up to as late as the 1960s), its relatively small population in comparison with other world regions (including North America, Europe, and emerging South and East Asia), and hence the limited size of its domestic market overall. ${ }^{7}$ However, the MENA economies' energy consumption has historically grown faster than most other regions' demand, peaking during the 1970s (a decade of vast energy-intensive expansion in the region's oil producers in particular). Since then, regional energy demand has continued to grow at high rates each decade, and although decelerating to its current level of above 2 per cent more recently, the MENA region is now second only to the fast-growing economies of South and East Asia (see Figures 1 and 2). Many large oil producing countries, particularly the Gulf states, have grown considerably faster than the regional average, both in absolute and in per capita terms. ${ }^{8}$ Aggregate Gulf demand, (including the GCC economies, Iran, and Iraq) for primary energy has risen five-fold since the 1980s, translating into the world's fastest energy demand growth for any region if disaggregated from overall MENA demand. ${ }^{9}$

\section{Figure 1: Regional Trends in Energy Use, Figure 2: Regional Trend in Energy Intensity, Compound Average Annual Growth, 1971- Compound Average Annual Growth in Energy 2010}

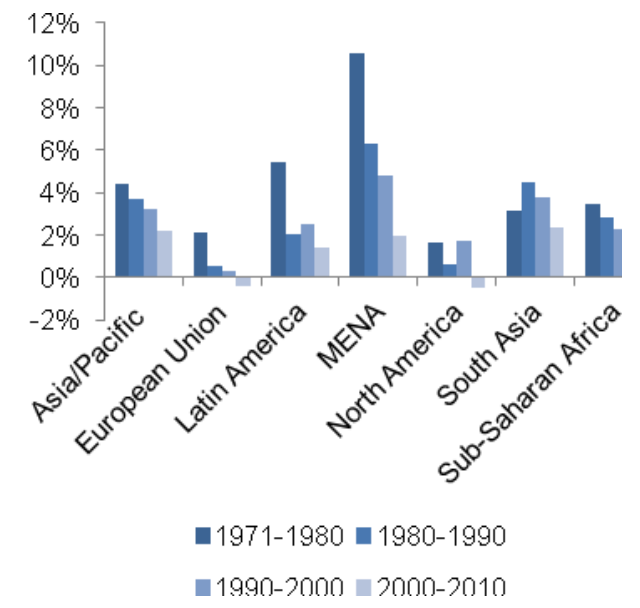

Source: World Bank (2013a).

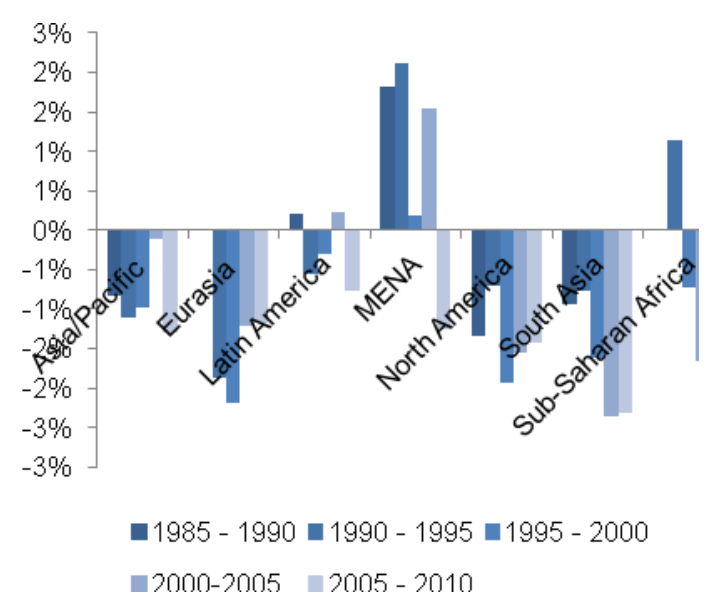

The key regional producers Saudi Arabia and Iran are now also major energy consumers. Over just a few years, Saudi Arabia has risen to be the world's sixth largest consumer of oil and natural gas; while Iran has been in the unique position of simultaneously holding the world's largest gas reserves while being both a net importer of natural gas to compensate for domestic production shortfalls and the world's third largest natural gas market after the USA and Russia. ${ }^{10}$

With expectations for continuingly rising living standards and large industrial investment programmes across many MENA oil and gas producers, the region's energy needs are forecast to continue to grow. OECD statistics suggest MENA aggregate energy demand is expected to continue to expand

\footnotetext{
7 For a detailed historical data analysis of the Gulf states (the GCC, Iran, and Iraq), see El-Katiri (2013b, 2-7, 25). 8 World Bank (2013a)

9 El-Katiri $(2013 b, 6)$

10 Data as of end-2012, BP (2013). Saudi Arabia's oil consumption is, at $2.9 \mathrm{mb} / \mathrm{d}$ in 2012, only a little less than the world's fifth largest consumer, Russia $(3.17 \mathrm{mb} / \mathrm{d})$, and the fourth largest consumer, India $(3.65 \mathrm{mb} / \mathrm{d})$. Iran's natural gas consumption in 2012 amounted to some $156 \mathrm{bcm}$, growing $11.7 \%$ from the previous year, which makes Iran third in natural gas consumption to the USA and Russia. Iran's status as an oil and gas exporter at the time of writing is under question owing, additionally, to international sanctions, which overshadow domestic energy policies as the main factor determining the country's export potential for the time being.
} 
well above the world average, at around 3 per cent per year between 2010 and 2030, with electricity demand growing at a rate of 6 per cent a year over the same period. ${ }^{11}$

Fossil fuels continue to supply the majority of the MENA region's primary energy needs, around 98 per cent of the region's energy mix - a historical pattern closely tied to the region's role as a global supplier of oil and natural gas since the 1950s. Other than oil and natural gas, only coal has an additional market share, albeit restricted to Morocco and Israel; ${ }^{12}$ while hydro-power accounts for the majority of the region's overall small share (a mere 2 per cent of gross regional primary energy consumption) of renewable energy (see Figure 3 ). Similarly, nuclear power has not yet made inroads into the region - with the exception of Iran's small but politically controversial nuclear programme. ${ }^{13}$

Figure 3: Share of Fuel Types in Total Electricity Generation by World Region, 2010

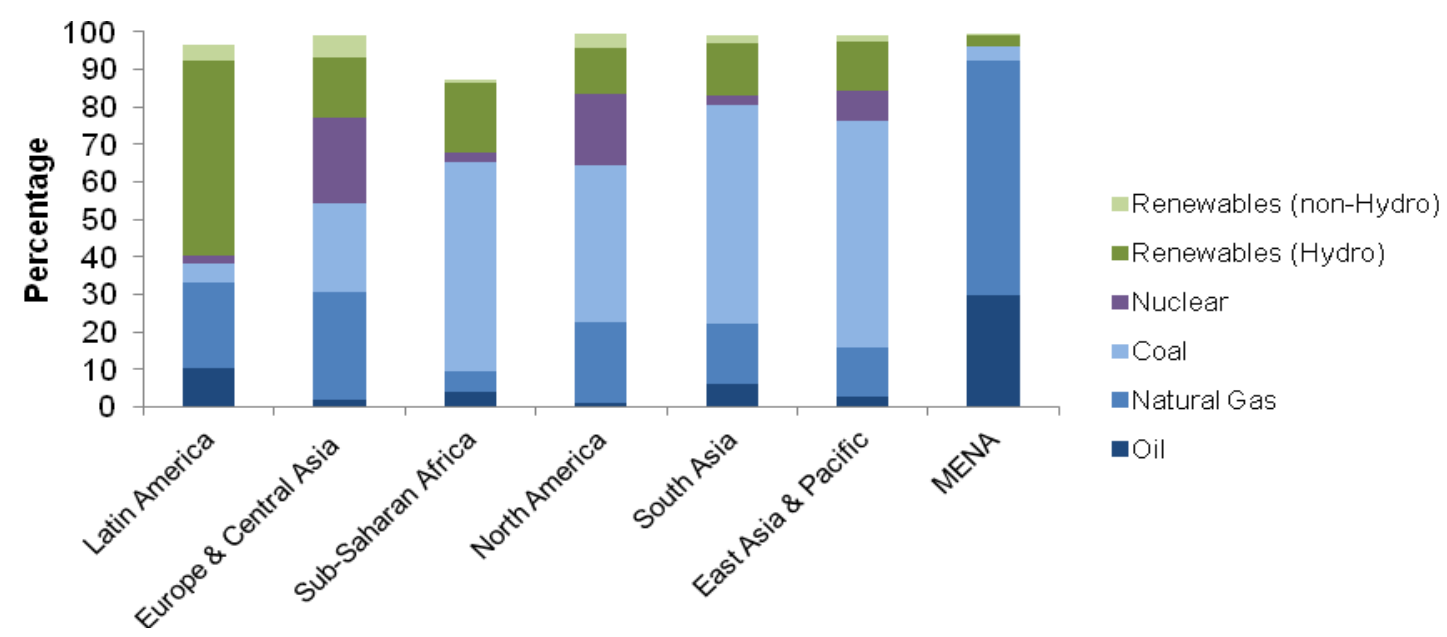

Notes: Percentages for Latin America and sub-Saharan Africa do not add up, reflecting existing limitations under regional data reporting. The balance is probably made up of traditional biomass. ${ }^{14}$

Source: World Bank (2013a).

\subsection{The rising economic cost of business-as-usual}

For many MENA economies, the security of energy supply question - that is, the provision of secure supply of energy at affordable prices ${ }^{15}$ - has historically not been a major area of policy concern. Supplies came from either domestic production or, in the cases of NICs such as Morocco, Jordan, and Lebanon, preferential contracts with other Arab countries, which limited the risk of any supply disruption. ${ }^{16}$

On the other hand, the affordability of energy to domestic MENA economies has historically been safeguarded by domestic government transfers. Such transfers are either explicit, in the form of energy subsidies in NICs, or implicit, via government-regulated domestic prices for oil and gas, as well as electricity, in NECs.

\footnotetext{
$11 \operatorname{OECD}(2013,10)$

12 World Bank (2013a). Dubai has, on several previous occasions, announced plans for a coal-fired power plant. Plans for a similar project in Oman have been abandoned due to local residential opposition and environmental concerns. Reuters (2013). 13 The UAE has the most advanced nuclear power plans in the Arab world so far, having contracted four 1,400 MW nuclear reactors to be built by 2020. Saudi Arabia, Egypt, and Jordan have also announced nuclear plans at different times in the past. See Rogner and Shihan-Eldin (2013).

14 Like all data used in this report, such data should be considered as indicative, rather than authoritative, given the difficulty in data in reporting across various regions and countries.

15 For instance, Yergin (2006).

16 Some of these contracts have been renewed, although at far higher price levels than during the 1990s, reflecting higher overall oil prices on global markets. For instance, see Al-Ghadd (2011); Ar-Ra'ii (2013).
} 
Since the early 2000s, rising global oil prices have significantly transformed the environment in which these historical economic deals between governments and their citizens have been conducted. MENA oil and natural gas exporters see this impact mainly implicitly: rising domestic demand for domestically produced oil and gas ties a growing share of their production capacity to their priceregulated domestic markets, and impacts their capacity to export their fossil fuels to high-price external markets instead. ${ }^{17}$ The resulting opportunity cost of domestic fossil fuel consumption in large oil and gas producers can be substantial, as the case of Saudi Arabia illustrates - Saudi Arabia's domestic energy consumption has grown fast over the past thirty years, leading the aggregate Middle East demand (itself one of the key regions expected to drive global demand growth well into the 2030s). ${ }^{18}$ Alongside Iran, Saudi Arabia is now the Middle East's largest energy consumer, accounting for a total of 3.5 million barrels of oil equivalent per day (boed) in $2010 .{ }^{19}$ Saudi Arabia's growing energy demand is seen in its rapidly rising industrial energy intensity and in its energy consumption per capita - both place Saudi Arabia firmly amongst the highly industrialized nations.

The surge in Saudi Arabia's domestic oil consumption over recent years has prompted concern, both within Saudi Arabia and amongst oil market observers abroad, as to the long-term outlook for domestic oil consumption inside the Kingdom, given the crucial role Saudi Arabian oil exports play on global oil markets. ${ }^{20}$ Saudi Arabia's own market size means the Kingdom is now the world's sixth largest consumer of oil in its own right. Saudi Aramco CEO Khaled Al-Falih has rung alarm bells, highlighting the possibility that a business-as-usual scenario in the Kingdom could result in its domestic consumption more than doubling (to 8.2 million boe/d, around two-thirds of the barrel equivalent of Saudi Arabia's export capacity in 2012) by 2030, in the absence of curbs on domestic demand for oil. ${ }^{21}$

Saudi investment company JADWA describes the potential for additional revenues to the Saudi fiscal system through a reallocation of domestically consumed crude towards export markets in the following way:

Potential impacts on the global price of oil aside, if all of the 2.4 million barrels per day consumed domestically in 2010 [that] were priced at $\$ 10$ per barrel for local consumers (more than what the electricity company and industrial consumers pay but less than our estimate for gasoline retailers), were instead exported, this would have generated additional oil revenue of around $\$ 60$ billion, on top of the $\$ 215$ billion received in oil export earnings. ${ }^{22}$

Economic losses incurred by rising fossil fuel consumption in the MENA region are also visible in net importing countries (NICs). Lebanon, Jordan, Morocco, and Tunisia have, for a long time relied, on what were often preferential oil supply contracts with allied Arab states such as Saudi Arabia and Iraq, but the gradual erosion of such contracts, together with the increased need to pay for oil supplies at prices based on international price benchmarks, has increasingly raised the cost of their energy imports. ${ }^{23}$ Both under old and new import contracts, the governments of NICs only recovered a fraction of the actual import cost from domestic energy users, who throughout the region have benefited from extensive subsidies on all types of energy, including transport fuel, household gas, and electricity, as well as on the fuel and electricity supplied to industrial users.

Typically reliant on fossil fuels for up to 100 per cent of their domestic primary energy supply, the MENA region's NICs face enormous fiscal costs associated with fossil fuel imports that already now

\footnotetext{
17 For a detailed discussion of the concept, see Fattouh and El-Katiri (2012a).

18 IEA $(2012 b, 76)$

19 EIA (2013).

20 Bloomberg (2012); Lahn and Stevens (2011); Platts (2012).

21 Platts (2012).

22 JADWA Investment $(2011,21)$. It should be noted that the net effect (increased Saudi production) of these domestic consumption savings made may themselves push down prices, thereby reducing the opportunity cost range suggested by the Jadwa calculations.

23 See fn16.
} 
render alternative energy options 'economic' in fiscal terms, irrespective of their cost competitiveness on a consumer-price basis. At an import price for crude oil verging on $\$ 110 / \mathrm{bl}$, even the more costintensive options of PV and CSP may reduce overall energy import costs, and hence the fiscal burden faced by governments. Jordan, for instance, which imports 96 per cent of its primary energy needs, had incurred an import cost for fossil fuels representing 20 per cent of its GDP by 2010, and only a little of this is recovered via final consumer prices for energy. ${ }^{24}$ Jordan's external debt rises along with its trade deficit (driven also by growing energy import bills), the Kingdom having been forced to turn to the IMF for help with serving its external debt. ${ }^{25}$

The economic and monetary value of both forms of cost (low regulated prices in NECs and energy subsidies by NICs) has to be paid for either way via budgetary allocations that could have been used elsewhere ${ }^{26} \mathrm{~A}$ recent OECD report on the MENA region captures this rising cost, arguing:

Rising energy demand and heightened geopolitical risks associated with the recent events in the Middle East and North Africa (MENA) region will increase upward pressure on energy prices in the coming years ... With little policy emphasis on energy efficiency and an intensive use of fossil fuels, the countries in the MENA region will be particularly exposed to the negative consequences of rising energy prices in the longer term, especially the small oil producers and net oil importers. To embed sustainable, long-term economic growth in the MENA region, countries must diversify their energy sources. ${ }^{27}$

\subsection{Environmental costs}

Environmental costs are rarely taken into consideration when determining the price of different fuel types used within an economy, a truth also in MENA economies. In large part, this is because the eventual economic costs caused by gradual environmental degradation and pollution associated with heavy use of fossil fuels are hard to quantify, and are largely external to the pricing formation process of energy. Similarly, the environmental benefits associated with renewable energy sources, such as lessened local pollution and a more favourable carbon emissions balance, do not form part of the pricing mechanism of energy in MENA countries - they hence accrue as positive externalities in the form of environmental benefit, and are not reflected in the price of different sources of energy.

There are, nevertheless, good reasons for MENA economies to consider environmental externalities as part of the package of wider social benefits that renewables have to offer to the region. Far from being immune to the effects of pollution from fossil fuel-based energy generation, water desalination, and industry, many MENA countries are indeed directly exposed to the negative effects of heightened air pollution and water contamination. They will also be exposed to the effects of climate change such as rising median temperatures, lower precipitation, and sea level rise - that fossil fuel-based emissions are believed to accelerate. ${ }^{28}$ The fishery industry, historically important across the MENA region, is particularly vulnerable to climatic changes such as increasing desertification, and deteriorating coastal water quality and temperature. ${ }^{29}$ While many middle-income countries in the Levant and North Africa, alongside other developing countries, argue that climate change mitigation must come second to more pressing poverty alleviation, the preservation of climatic conditions that

\footnotetext{
${ }^{24}$ Energy Charter Secretariat $(2010,6)$.

${ }^{25}$ Energy Charter Secretariat $(2010,6)$.

${ }^{26}$ Fattouh and El-Katiri (2012a, 18).

${ }^{27}$ OECD $(2013,9)$.

28 E.g. see Solomon et al. (2007); Luomi (2012).

29 The impact on human and animal life of fossil fuel-induced pollution and overall climate change is complex and is the subject of intense controversy over causalities. What remains unquestioned is the highly negative impact on human health which results from polluting activities that involve energy and industrial production based on burning fossil fuels, in particular oil. Human-induced environmental changes (such as rising temperatures on land) have very severe impacts on land availability and on its suitability for cultivation, by causing desertification, and less rainfall overall. Rising temperatures at sea, combined with additional environmental pollution (for instance, via artificial land reclamation), and overfishing, severely reduce biodiversity and impact fisheries, the lifeline for people across coastal MENA countries.
} 

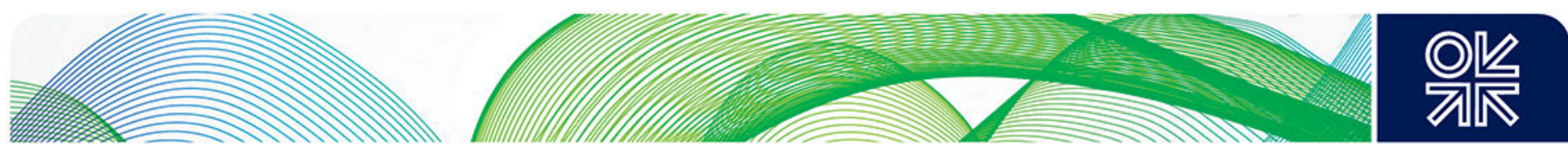

ensure sustained access to arable land and agriculture, and to fishing resources at sea, are important long-term goals that would render environmental considerations not so much of a 'luxury' concern for these countries after all. ${ }^{30}$

The MENA region's considerable reliance on oil and gas, as well as its associated focus on energyintensive industrialization projects that make further use of domestically produced hydrocarbons, has also left a mark on the region's carbon footprint, which has grown dramatically since the 1960s alongside rapid rates of urbanization, energy-intensive industrialization, and rising living standards (see Figures 4 and 5).

\section{Figure 4: Per Capita $\mathrm{CO}_{2}$ Emissions by Region, 2009}

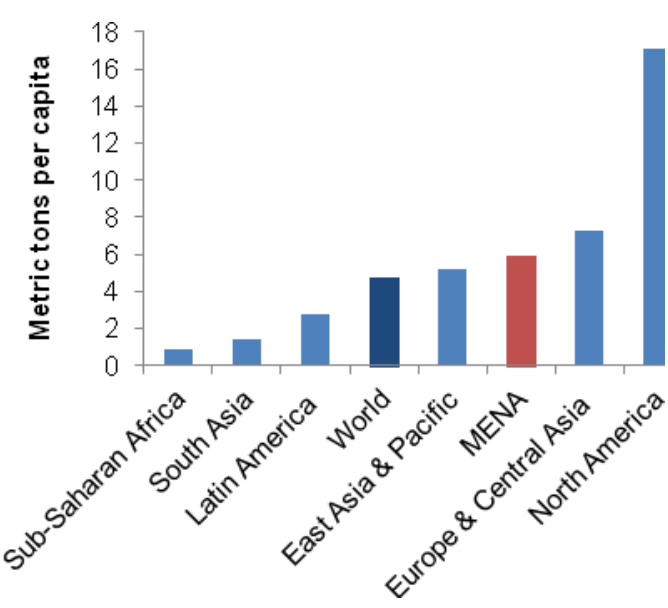

Source: World Bank (2013a).

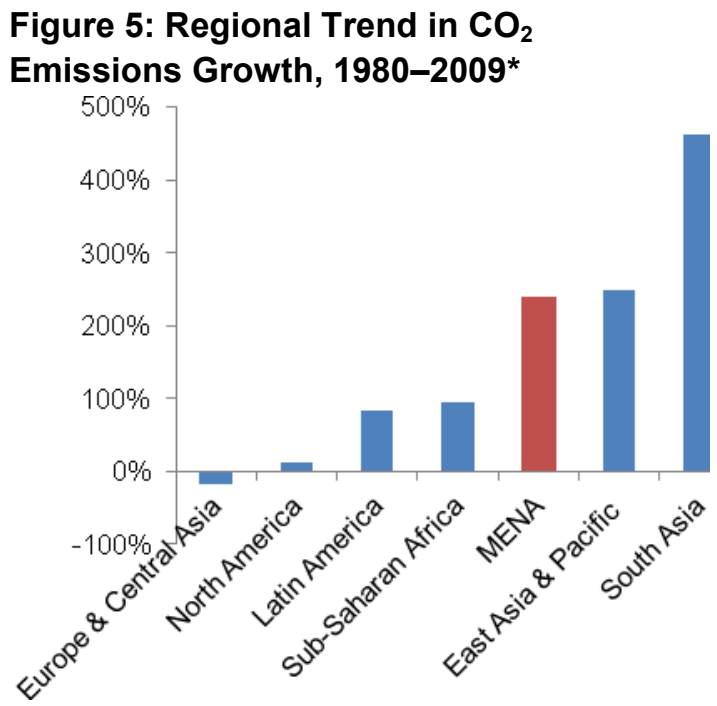

Source: World Bank (2013a).

Notes: *Share for Eurasia for 1990-2009 due to data limitations

Concern for the negative impact of climate change has been voiced on various occasions by policymakers in the region. Arab heads of state signed the Damascus Declaration of 2007, stating their commitment:

$\ldots$ to take necessary measures and develop competent plans to enhance renewable energies in their countries' energy portfolios. ${ }^{31}$

Despite some variation between different technologies, renewable energy sources generally offer considerable environmental advantages vis-à-vis fossil fuels. The life-cycle $\mathrm{CO}_{2}$ emissions of renewable energy are significantly lower than those of fossil fuels, rendering most renewables an environmentally friendlier option than many other energy alternatives. ${ }^{32}$ Wind, solar, and hydro/waterbased energy technologies generate no emissions during operation, whilst biomass and geothermal energy generate significantly lower emissions than traditional fossil fuels. ${ }^{33}$ El Fadel et al. show in a

30 Reddy extensively outlines the argument put forward by many developing countries against renewables as being an economic 'luxury' that corresponds primarily to highly developed countries' environmental protection agenda. Reddy (1991). For an assessment of MENA countries' vulnerability to climatic change, see Solomon et al. (2007, 847-940) (Europe and the Mediterranean, and Asia).

31 MENAREC 4 (2007).

32 IEA (2011a), 68; see also Cherubini et al. (2009); POST (2006). Some renewable energy sources, such as biomass, bioenergy such as waste-to-energy, and large hydro-projects come with their own environmental problems, the discussion of which would reach beyond the scope of this paper. Standard technologies such as solar and wind power, the most important options used in the MENA, come with a reasonably lower impact through emissions and overall environmental degradation than fossil fuels.

33 Environmentally, some technologies raise fewer concerns than others; both solar and wind technologies, for instance, involve little environmental controversy - land use being one area of concern, particularly in highly populated areas. Offshore wind farms, hydro, geothermal, and biomass energy, by contrast, raise a number of environmental concerns, including marine 

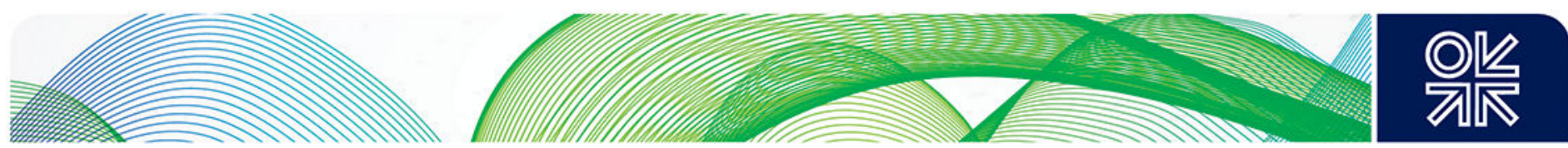

simulation the enormous emissions reduction potential of a sectoral introduction of renewable energy in the MENA region up until 2040. ${ }^{34}$

Many renewable energy technologies also impact the environment significantly less than alternatives, owing to their limited technical risk. The risk of environmental disaster in the case of technical fault or manmade error - such as the contamination of air, land, or water - is unequally smaller with wind, solar, or even biomass plants than in the cases of fossil fuel-based plants or of nuclear power - the other energy supply alternative of several MENA economies. Such considerations also render renewable energy a technology that is socially compatible with many parts of the population - in sharp contrast with the more polluting energy technologies such as coal or new oil-fired power plants, and nuclear energy, whose introduction faces significantly more social hurdles, and not just in the MENA region. The main concern around renewables is hence not about their acceptability, or the social benefit they may generate, but relates to their scale and economic feasibility.

\section{Barriers to Renewables Deployment in the MENA}

Key to determining any technology's deployment is its comparative cost advantage vis-à-vis existing technologies. Renewables in this equation have always faced more difficulties than most other energy technologies, in the main because of the lengthy lifecycles required to recover their high initial capital costs, the absence of any meaningful way to consider externalities in the calculation of the full cost of renewable and non-renewable energy sources, and the additional cost of integrating intermittent energy sources into stable power systems. ${ }^{35}$ At the same time, the MENA region is widely seen as one of the best locations for solar energy, with high-value wind locations in some MENA countries, suggesting that regional lifecycle costs for renewables could lie well below those in most other regional markets, such as Europe and North America. ${ }^{36}$ So why have renewable energy sources not been taken up by MENA economies to a larger extent? The answer lies in the MENA region's particular energy market structures, most importantly in the way in which energy is priced domestically. Below, we discuss how existing regional energy pricing mechanisms impede a sensible cost comparison between renewable and conventional sources of energy in the MENA region, to the disadvantage of renewable energy.

\subsection{Electricity pricing in the MENA region}

The political economy of energy in the Middle East and North Africa has always been characterized by a set of unique regional factors:

- $\quad$ primarily, the availability of large supplies in conventional oil and gas resources;

- $\quad$ the pivotal role played by hydrocarbon wealth in many MENA oil and gas producers' economic development since the 1960s and 1970s; and

environmental degradation (in the case of offshore wind), the environmental consequences of large hydro-installations in the form of flooding and impacts on existing water systems, and the polluting effects of geothermal energy production on air and water resources. DLR $(2005,163-8)$.

34 El Fadel et al. (2013).

35 Intermittent energy supplies are interrupted by the absence of the climatic or environmental condition on which its energy flow is based, for instance in the case of absent or variable wind strengths, and the absence of daylight and sunshine by night. Integrating intermittent energy supplies is often seen as a challenge - if not in developed economies, then certainly in developing economies with weak power sectors. Technology itself is not so much the problem here as a lack of experience, as well as poor utility company funding (often in the presence of a state monopoly on the entire utility sector value chain), poorly maintained electricity grids, and (what is perceived to translate into) a lack of access to modern metering and smart grid technology. Nevertheless, technical solutions do exist, rendering the integration of intermittent renewable energy sources more an issue of cost than of technological feasibility. E.g. see EEA $(2001,52)$.

36 DLR (2005); OECD (2013); IRENA (2013b); Karakosta and Psarras (2013); Stambouli (2011); Vidican (2012); Razavi (2012); Pejat et al. (2013); Dehghan (2011); Kazem and Chaichan (2012); Al-Saleh et al. (2008); Saudi Arabia Solar Industry Association (2013). See also Appendix II. 

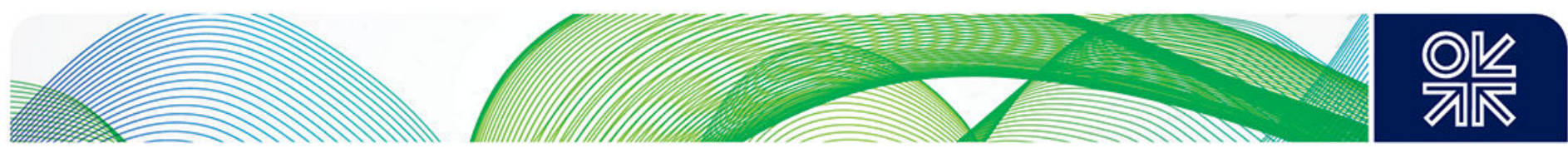

- $\quad$ the particular social contract (resulting from the first two factors) in many MENA countries where energy has, for many decades, been considered something of a public good to be provided by governments, if not for free, then at prices that have in many cases been merely a fraction of their price in any other international market for most of these countries' modern histories.

The resulting pricing structures span across different fuel types and electricity, and involve explicit and implicit government transfers to producers of fossil fuels and utilities, importers, and distributers in addition to direct consumer subsidies.

Electricity prices illustrate the MENA-wide policy of providing low-cost energy supplies to both households and industries (see Figure 6). ${ }^{37}$ Kuwait's average residential electricity tariff of less than one US $\phi / k W h$ electricity stands out as the world's lowest electricity price, in place unchanged since the 1970s. Other GCC states - Iraq, Syria, and Yemen, with prices below $2.5 \mathrm{US} \phi / \mathrm{kWh}$ - charged less than a quarter of the average electricity prices in liberalized markets such as Europe and North America in 2008. Average prices conceal the variation of price levels by consumption groups, which in some cases can lie significantly below those tariffs shown, for particular consumer groups.

\section{Figure 6: Cross-Country Comparison of Average Residential Electricity Prices in Selected MENA and non-MENA Countries, 2008}

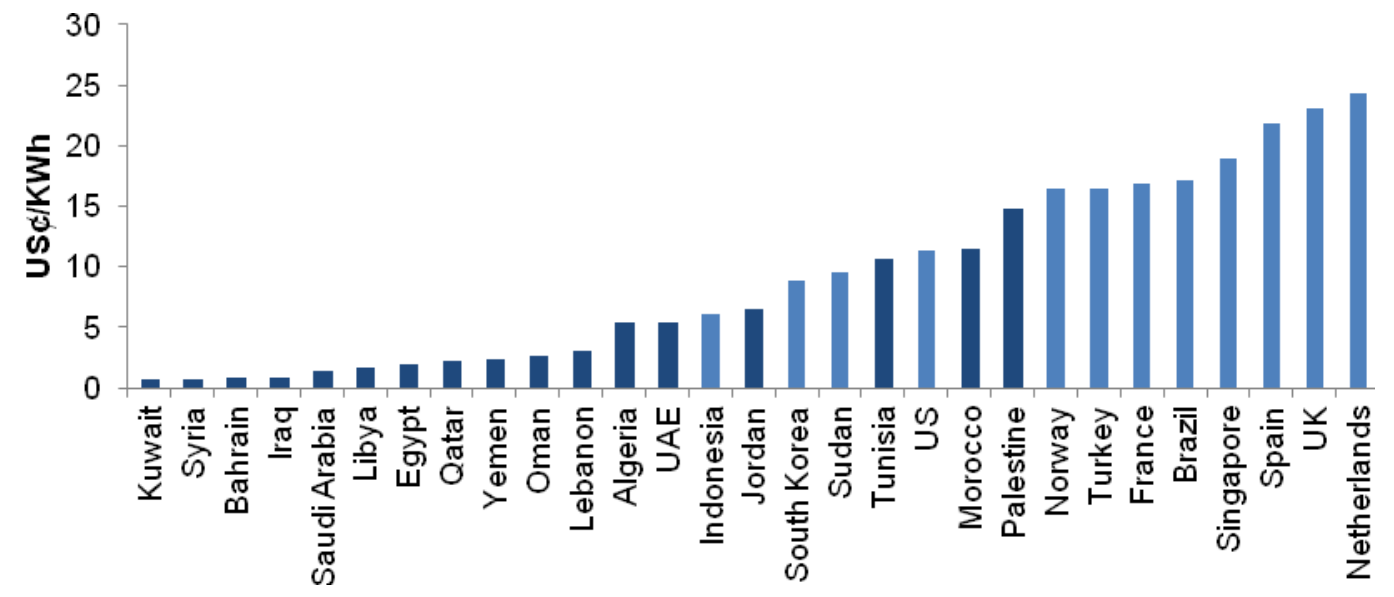

Source: El-Katiri, Fattouh and Segal (2011); EIA (2013)

Only Morocco and the Palestinian territories match European levels, thereby being exceptions to the otherwise low-cost environment for Middle Eastern electricity - both countries are reliant on international imports of oil for power generation, and Morocco imports Spanish power, being unable to supply its own market (a fate it shares with many of its MENA neighbours). Nevertheless, both the Moroccan government and the Palestinian authorities subsidize electricity prices, suggesting that actual generation costs may well exceed these already high price levels - rendering their domestic electricity generation exceptionally expensive even by international comparison.

Using Levelized Cost of Energy (LCOE) estimates to compare price ranges for renewable and conventional energy alternatives, it appears relatively clear at first sight that any economic cost-saving potential for renewable energy is in fact difficult to demonstrate given these domestic electricity tariff ranges. ${ }^{38}$ At an LCOE of between US $\phi 11-\phi 48 / \mathrm{kWh}$ for utility size installations and US $\phi 13.8 / \mathrm{kWh}$ for

37 We use 2008 data for the cross-comparison as the latest available international data from the EIA is only available for 2008. 38 The Levelized Cost of Energy (LCOE) estimates the cost of energy sources based on their lifecycle costs, including: initial capital cost, factors such the fuel type's capacity factor, the cost of equity, the cost of debt, operating costs, and expected fuel costs for a given technology. It is widely used to compare the costs of different fuel technologies that may differ in terms of the size of the initial capital cost, the fuel cost, etc. The LCOE is an imperfect measure subject to various assumptions based on local conditions, but it provides us with the most practical way of making different technologies more comparable. Useful references for recent, more elaborate work on LCOE calculation methods and/or analysis include NEA/IEA/OECD (2005); 
rooftop installations of typical solar PV models, and between US $\phi 6-14 / \mathrm{kWh}$ for onshore wind, the average LCOE for even lower-cost renewable energy technologies will exceed the domestic price for electricity across the vast majority of MENA countries. ${ }^{39}$

A look at disaggregated data for residential, commercial, and industrial power use for 2012 nevertheless opens up some material for thought: prices for industrial and residential/commercial users differ significantly in many MENA countries, for varying reasons including cross-subsidies for residential and commercial users, or a simple tendency to shield industrial electricity prices less against rises in electricity generation costs than residential users (see Figure 7 ) ${ }^{40}$ While still tame in some larger oil and gas producing countries, such as the GCC economies and Algeria, the size of these industrial tariffs could provide some economic opportunities for renewable energy technologies in industrial use or, conversely, allow for more generally adjusted electricity tariffs. In Morocco, for instance, (one of the MENA region's highest priced markets for electricity) average residential electricity tariffs stand at $\phi 11 / \mathrm{kWh}$, but the price for commercial customers is more than three times as high, at $\phi 35 / \mathrm{kWh}$, while industrial consumers pay a high $\phi 133 / \mathrm{kWh}$. At these prices, even high-cost CSP technology could deliver a cost-effective electricity supply when this is compared with the high cost of Morocco's oil-fired power plants. This case could indeed be made for industrial users in most MENA countries, including Algeria, Egypt, Jordan, and several of the GCC economies. This data also offers an important indication of where electricity prices in the MENA region could be, if subsidies on direct electricity and on input fuels were transparently removed.

\section{Figure 7: Residential, Commercial, and Industrial Electricity Prices in Selected MENA}

\section{Countries, 2012}

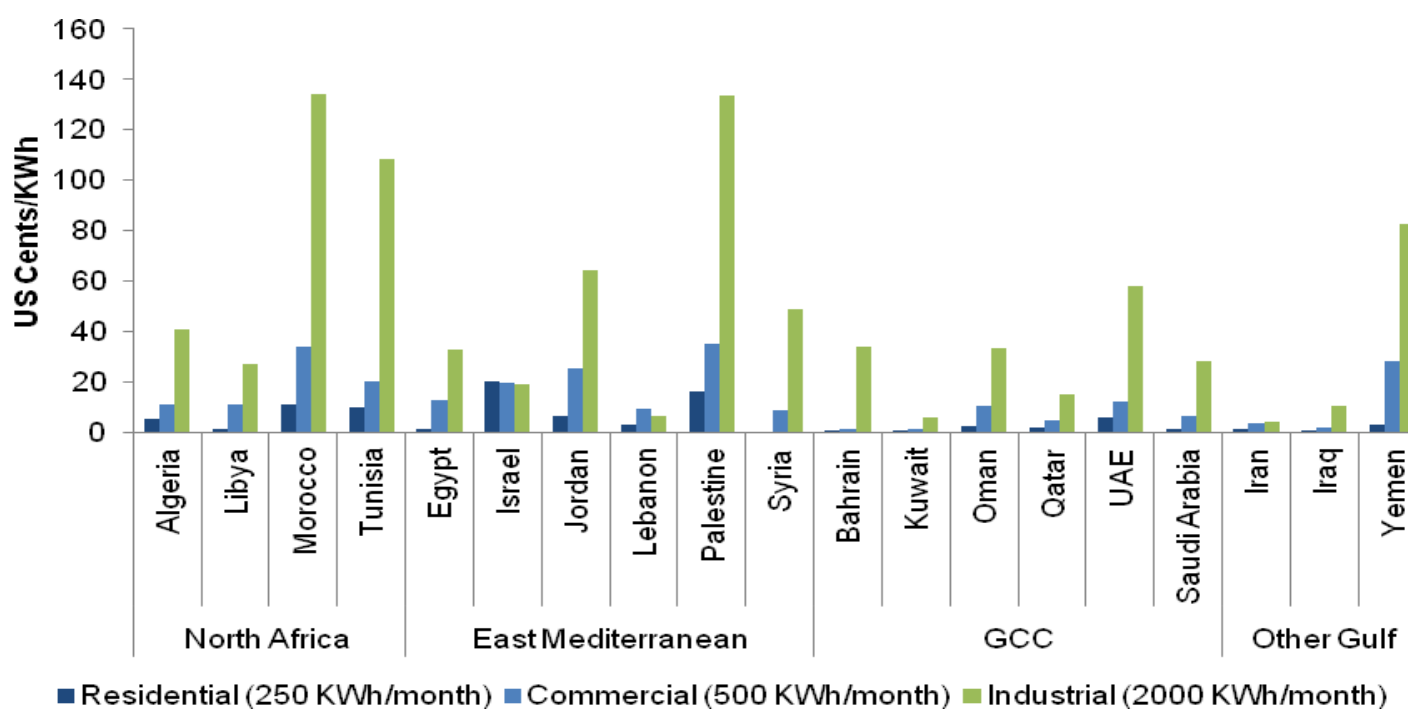

Notes: Prices are averaged between (where applicable) dynamic night- and day-tariffs. Iran's highly fluctuating exchange rate makes a meaningful valuation of electricity prices in $\$$ terms difficult. We have used an exchange rate of IR30,600:\$1. Iranian electricity prices are as of $2013 .{ }^{41}$ UAE prices are based on Abu Dhabi in the

Singh and Singh (2010); Zweibel (2010); Branker et al. (2011); Darling et al. (2011); Wang et al (2011); BNEF (2011). For a thorough discussion of the advantages and limitations to the concept, see Appendix I.

39 Solar estimates based on EIA, wind on IRENA estimates. CCC (2011, 22-3); IRENA (2012); See Appendix II for a costcomparison table. All reservations about the validity of LCOE estimates discussed above remain.

40 In some cases, industrial users may also cross-subsidize residential and commercial users. There is no publically available information on such practice other than case-based narratives.

41 We used the free market quotation for Iranian rials at end-October 2013, which differs significantly from the official exchange rate of Iran's Central Bank. Iran's highly devalued currency distorts this cost comparison, allowing only limited conclusions at this point of time. 
absence of detailed price data for all seven emirates. Israel: average tariffs, excluding special (subsidised) tariffs applied to Palestinian Authority.

Source: Arab Union of Electricity (2012); Tavanir; Israeli Public Utility Authority.

\subsection{Domestic pricing of fossil fuels}

An important part of the wider picture of low electricity prices is hence the price of conventional fuels such as diesel, fuel oil, and crude oil. Crude oil is used by a number of oil producers to compensate for insufficient gas supplies during peak demand in summer, and natural gas is supplied to domestic industries such as power generation. As the mother-of-all subsidies, the MENA region as a whole continues to subsidize and under-price domestically supplied fossil fuels to an extent that will render alternative renewable energy sources uncompetitive on a cost basis even where genuine economic value would be generated, for instance via saved imports or the availability of more oil and natural gas for exports.

Only in NICs can the size of the resulting energy subsidy (the difference between import cost and the price at which energy inputs are sold domestically) be determined; this is usually done by deducting the domestic price charged for energy imports from their import price. There are, however, many other forms of indirect subsidies - concessionary loans, government guarantees, land grants, tax incentives, R\&D spending, liability insurance, leases, land rights-of-way, waste disposal, and guarantees to mitigate project financing or fuel price risks and potential commercial losses made by public utility companies and carried over by quasi-fiscal transactions - which cannot be reflected by such measures. ${ }^{42}$

Conventional measures of subsidies are not able to capture the economic value lost by NECs (such as Saudi Arabia) for any given energy product - be it crude oil, refined products, or natural gas - that is lost to the international market and sold domestically at a fraction of its international market value. This poses a problem for the economics of energy, and the commercial valuation of energy resources in many MENA oil and gas producers. Unwilling to consider the opportunity cost (the cost associated with value lost for fossil fuel sources priced domestically below their economic value on international markets) as being a 'subsidy', many MENA producers refer to the long-run marginal cost of production per unit of energy as the relevant benchmark framework for evaluating the cost of domestically produced fossil fuels vis-à-vis renewable and other alternative sources of energy. ${ }^{43}$ The subsequent paper-based cost comparison between both renewables and nuclear on the one hand, and regionally produced fossil fuels on the other is hence absurdly asymmetric, particularly in the case of crude oil and oil products. The value lost to NECs is in the form of: wasted energy, a more rapid depletion of these countries' hydrocarbon resources, and consumer subsidies that benefit primarily large users of energy, and while not quantifiable in the conventional sense, it can only be thought of as being excessive.

An example illustrates this dilemma. In 2012, Saudi Arabia's domestic price for electricity resulting from its assumed input costs (the long-run marginal cost of production per unit of energy), started at $\$ 0.013$ per kilowatt hour for residential users and $\$ 0.036$ per kilowatt hour for commercial users. However, the Saudi Electricity and Co-generation Regulatory Authority (ECRA) suggests that none of these tariffs is cost-reflective, irrespective of the already low costs for input fuels. ${ }^{44}$ It is clear from these numbers that RES technologies such as solar (between US $\phi 11-\phi 0.48$ for PV and US $\phi 18-$ $\phi 30 / \mathrm{kWh}$ for CSP) ${ }^{45}$ and wind (US $\left.\phi 5-\phi 16 / \mathrm{kWh}\right),{ }^{46}$ despite significant cost falls over the past few years, find it difficult to offer a commercially attractive option. A recent King Abdullah City for Atomic and Renewable Energy (K.A.CARE) study confirms that under current domestic cost assumptions for

42 Beck and Martinot $(2004,366)$.

43 E.g. Luciani (2010, 33-4); for a broader discussion, see IEA, OPEC, OECD and World Bank (2010)

44 JADWA Investment (2011, 21); El-Katiri (2011, 8, fn16).

45 Brown et al. (2011, 36); See also Appendix II.

46 REN21 (2011); See also Appendix II. Wind costs at the lower end would already be competitive on some higher-price electricity markets such as Morocco. 
alternative oil and gas-fired power generation, neither renewables nor nuclear power offers any material cost savings. ${ }^{47}$

Are alternative energies in Saudi Arabia hence uneconomic? The answer is highly sensitive to the underlying cost price assumptions made under current Saudi market conditions. Saudi Arabia, as one of the world's lowest-cost energy providers to its domestic market, supplies natural gas to domestic power producers at a mere $\$ 0.75 / \mathrm{MMBtu}$, and oil at $\$ 2.7-\$ 4.3 / \mathrm{barrel}(\$ 0.47-\$ 0.74 / \mathrm{MMBtu}){ }^{48}$ The Saudi domestic industry price for crude oil and oil products lies significantly below international market prices - the price Saudi oil would be able to fetch if exported rather than used domestically. A 2013 White Paper published by the Saudi Arabia Solar Industry Association makes this point, using static international prices to reflect the kind of opportunity cost Saudi Arabia encounters under its current domestic energy price model:

On average 1.3 barrels of oil are required to generate one MWh of electricity - 1.3 barrels worth 139 USD that cannot be sold on the world market. Thus, the opportunity cost for the usage of oil for electricity production is 139 USD per MWh, respectively 0.139 USD per kWh. ${ }^{49}$

While the precise level of opportunity cost is likely to be less straightforward than suggested in this calculation, it is clear that Saudi Arabia is incurring a cost - albeit implicitly - that is not reflected under current fuel prices and it hence influences domestic fuel pricing incentives negatively towards energy alternatives such as renewables. Indeed, assuming the above suggested kWh price of US $\$ 0.139$, the comparable price of CSP in Saudi Arabia would come in (at $\$ 0.175 / \mathrm{kWh}$ ) with a considerably lesser cost disadvantage than under current price assumptions - all of this being based on very tentative assumptions, given the absence of official Saudi cost estimates to confirm these rule-of-thumb estimates. Saudi natural gas is similarly low-priced at $\$ 0.75 / \mathrm{MMBtu}$, about five times less than the US Henry Hub average in 2013 and a mere a fraction of the projected cost of new, nonassociated gas development costs in Saudi Arabia's Empty Quarter and the Red Sea coastal offshore areas (with a cost range of US\$3.50-\$5.50/MMBtu). ${ }^{50}$

Natural gas importers face very different cost profiles to start with, as the expected cost of new LNG imports may range rather above a conservative estimate of $\$ 10 / \mathrm{MMBtu}$ - sufficient to render renewable energy projects viable in NICs with no own gas production. Kuwait's domestic gas price to industry (\$2/MMBtu), for instance, already lies at the higher end of the MENA region's price spectrum, implying an explicit subsidy for imported gas supplied of above $\$ 8 / \mathrm{MMBtu}$. The process of comparing the LCOE for renewables vis-à-vis natural gas in Kuwait would arguably need to include the expected long-run cost of gas including all import costs, in order to assess the net-benefit of each energy source, with solar probably offering cost benefits in view of the relatively high cost of LNG. The Emirates Solar Industry Association (ESIA), for instance, has shown that the LCOE from solar PV in typical MENA climates (estimated to be $\$ 0.15 / \mathrm{kWh}$ ) makes PV cheaper on a simple LCOE basis than open-cycle peaking units at gas prices higher than $\$ 5.00 / \mathrm{MMBtu} .^{51}$ This condition is likely to be fulfilled by all importers of LNG (though not pipeline gas) and by some of Saudi Arabia's higher-cost gas projects. Large natural gas exporters such as Qatar may also include factors other than the marginal cost of producing gas in their cost considerations - including a cost provision to reflect the depletion of the country's valuable gas resources at a faster pace and the erosion of export capacity over time - in a similar way to the process adopted by oil exporters.

The economics of renewables versus oil differ substantially from those of renewables versus natural gas because of the far higher opportunity cost of oil and its high value as an export product. While the calculation of a static international shadow price for oil as a benchmark for domestic oil pricing is

47 Energy Intelligence Finance (2011).

48 ESIA $(2012,10)$; JADWA reports Saudi ECRA pays Saudi Aramco US $\$ 4.3 / \mathrm{bbl}$ for light crude and US $\$ 2.7 / \mathrm{bbl}$ for heavy crude, which JADWA believes reflect prices to other industrial users as well. JADWA Investment $(2011,21)$.

49 Saudi Arabia Solar Industry Association $(2013,7)$.

50 MEES (2013b)

51 Bazilian and Roques $(2008,10)$; ESIA (2012). 
undoubtedly problematic, the moderate assumption of a domestic price of $\$ 60 / \mathrm{bl}$ in the above K.A.CARE report already demonstrates the viability of renewable power options - falling short of some more drastic cost demonstrations made by other reports. A 2011 Bloomberg study similarly concludes that falling costs of PV technology mean that solar energy is already a viable option for power generation in the region when used to replace the burning of oil, as long as that oil is valued at the international selling price. Even under the report's low-price scenario of $\$ 80 / \mathrm{bbl}$, solar PV plants are cost-competitive with oil-fired power generation. ${ }^{52}$ The study concludes that

Any assessment of the economics of PV in the GCC depends critically on whether the comparison is with the extraction cost of oil or - surely more correctly - its international market price. If extraction costs are used as the comparator, then $\mathrm{PV}$ is uneconomic and will remain so for the foreseeable future. ${ }^{53}$

A 2012 ESIA study reaffirms these results, showing that, with oil prices at about $\$ 80 /$ barrel, or natural gas prices above US $\$ 13 / \mathrm{MMBtu}$, solar PV projects become commercially viable in the MENA's generation mix without the need for subsidies. Solar power under this model is cheaper than a conventional open-cycle unit at peak production with gas prices:

$\ldots$ above $\$ 5 / \mathrm{MMBtu}$ (equivalent to oil at around $\$ 30 /$ barrel), but requires $\$ 17 / \mathrm{MMBtu}$ to be competitive with base-load combined-cycle power - around current LNG prices. ${ }^{54}$

The break-even prices under this model are expected to fall further, as solar power costs continue to drop. ${ }^{55}$ The study concludes that:

... as imported fuel (gas or oil) prices increase, solar power will increasingly become a viable part of the [MENA region's] generation mix. ${ }^{56}$

Other country studies support the argument that domestic energy subsidies - unique both in scope and size in the MENA region - have constituted an important stumbling block to the adoption of renewable energy both inside and outside the MENA. ${ }^{57}$ An account from Egypt provides a picture of this problem - a problem which ranges even beyond mere price comparisons to the dissemination of technology within the national energy market:

In Egypt, and across the region, energy subsidies are the 'Achilles' heel' of the energy sector. Through their impact on energy prices, subsidies distort incentives for consumers (by reducing demand for clean energy, which costs more for individuals and commercial consumers) and for the private sector (by increasing investment costs for manufacturers of renewable energy parts and components, as well as for service providers, because of the limited and unpredictable market). Energy subsidies have also been shown to limit technology transfer of more than intellectual property rights such as patents for renewables ... Energy subsidies can thereby 'lock-in' some technologies to the exclusion of others that are more promising, such as renewables ... Faced with an already overburdened budget, the financial incentives required for renewable energy deployment are perceived as unaffordable, thus preventing the formation of coalitions for change ${ }^{58}$

\footnotetext{
${ }^{52}$ BNEF (2011).

53 BNEF (2011).

$54 \operatorname{ESIA}(2012,8)$.

55 ESIA $(2012,14)$.

$56 \operatorname{ESIA}(2012,8)$.

57 E.g. Vidican (2012); Razavi (2012); Patlitzianas et al. (2006); ESIA (2012), 10; Bazilian and Roques (2008, 9).

58 Vidican, G. (2012, 99).
} 


\section{Promoting Renewables in the MENA Region}

How can renewable energy be promoted more inclusively and, most importantly, efficiently within the MENA region's own economic context? We suggest several different routes, some of them complementary:

(i) the economics of the first best: reforming regional energy pricing mechanisms, and bringing in the private sector, thereby addressing regional energy market distortions in the first place; and

(ii) the economics of the second best: fiscal and regulatory incentives to reduce the cost disadvantage of renewables vis-à-vis fossil fuels - in line with other, industrialized markets.

Renewable energy and its commercial and wider social benefits may also be realized more effectively when it is:

(iii) integrated within wider national energy strategies by specifically targeting those positive externalities that are not typically priced into the cost of renewables through the electricity tariff (as long as cautious policy ensures positive externalities are based on actual economic value generated).

\subsection{The economics of the first best: market incentives}

Creating the right incentives for renewable energy deployment in the MENA region can involve a toolkit of economic policies that reduce or eliminate market distortions that have kept renewables from entering the MENA market in the first place, in combination with the incentives that markets generally need: access to sources of finance and overall political support. The economic savings made by moving via this route can be substantial. The removal of distortions not only results in direct economic savings (via the reduction of energy subsidies, for instance) but also indirect savings through a reduction in deadweight loss (for instance through energy waste and unabated energy consumption growth where energy comes at a value close to zero to the individual user).

The political difficulty is considerably larger than that associated with second-best economic policies. However, economic gains and a sensible national approach that ensures market incentives create tangible social and economic benefits for all citizens, could create a real opportunity for renewable energy to be part of a wider structural reform of domestic energy markets.

\section{Energy market liberalization (i): Reforming domestic energy prices}

Perhaps the most potent tool for MENA economies in the promotion of renewables is the reform of domestic energy pricing frameworks, in order to reflect the comparative economic value of each energy technology. Given the international price for both oil and natural gas, the high degree of fossil fuel-reliance by MENA economies, and the comparative locational advantages of renewable energy technologies (such as solar) in many MENA countries, the economic value of renewables could be apparent on a cost basis even without the dedicated policy tools and subsidies on renewable energy which are seen in Europe and North America. Using cost-reflective prices as principle indicators of market forces (the 'invisible hand') rather than policy-induced targets and incentives also reduces the margin for the creation of new distortions and economic loss, helping markets absorb renewable energy where it will result in economic savings, while it prevents markets from wasting resources in cases where renewables won't generate value.

Allowing this cost advantage to induce renewables investment would be a very effective and valuegenerating way of encouraging such investment, for the market would only pick up on renewables investments that are financially advantageous in comparison to the use of conventional energy sources. Little additional regulatory or financial capacity by the state would be needed, which renders domestic pricing reform in theory the most effective, and most developing country-friendly way of encouraging renewable energy uptake. In reality, the problematique of reforming domestic energy prices is large, both politically and economically, in developing economies - even more than it is in highly industrialized countries. In some of the MENA region's middle income economies, the resultant 
increase in electricity prices from an adjustment of fuel prices into the power industry could arguably add to the economic hardship of its citizens, especially those in low-income households. Birdsall and Subramanian highlight this relationship when they write in the developing economies' context:

First, and foremost, we posit that from an ethical perspective, what is primary is not the 'right' to pollute, but access of people as consumers, independent of where they live, to basic energy-based amenities - such as meal preparation at home, pleasant ambient temperatures indoors, and/or access to transportation ensuring personal mobility, at reasonable cost. ${ }^{59}$

In many oil and gas-producing countries, such as the wealthy GCC economies, the particular historical relationship between hydrocarbon wealth and economic development on the one hand, and the unspoken social contract between rulers and ruled on the other, prohibits the application of international export prices as a benchmark for national energy prices, in the eyes of many, when energy, alongside water, is supposedly an almost-free gift of the state. The same relationship does not exist in the MENA region's NICs which, however, face the prospect of large popular protests, threatening the stability of their political status quo - in this context reform seems difficult, although desirable from an economic point of view. The reduction of economic waste and reallocation of economic resources in more productive ways which would result from such reforms would eventually help generate more economic opportunities for everyone, while the higher costs faced by the poorest in particular could be compensated by re-channelling the savings made via direct welfare systems or by universal cash transfers - thereby also delinking access to benefits and energy consumption.

Avenues into energy price reform in the utility sector across MENA countries will necessarily need to entail locally-specific, creative methods which ensure that the needs of the least well-off are as much protected as those of employment-creating industries that rely on electricity at a certain price. One of these avenues can be the use of external funding options, such as loans, grants, and guarantees by bodies such as the World Bank and the IMF, to make initial investments into renewable energy projects in less well-off economies. This option requires time, however, which few countries with acute fiscal crises have available. Gradual pricing reforms, coupled to more dynamic tariff systems for industries, and improved social systems for low-income households can help lower the social cost of higher electricity tariffs, while savings in electricity costs over time will contribute to the availability of larger funds for social safety programmes. State-led initiatives that enable households and industries to invest into energy efficiency can help reduce energy costs in the presence of rising electricity prices, reinforcing the need for pricing reform to be part of a larger economic plan that involves the use of savings to the benefit of energy users, while decoupling these benefits from the actual consumption of particular fuels. ${ }^{60}$ Many of the MENA region's better-off economies, such as the GCC states, will not need this support - financing options exist, and potential savings to be made are significant - justifying ideas such as alternative universal spending mechanisms, or well-targeted welfare transfers in countries such as Saudi Arabia.

\section{Energy market liberalization (ii): Bringing in the private sector}

Creating a functioning market in which incentives are at work involves the creation, and opening of, the market itself to different participants. Private sector participation in utility provision could indeed be a critical factor in encouraging investment, both in new overall capacity, and in renewables-based capacity itself. Private sector participants bring financial capital and can shoulder project risk, in addition to their role in acquiring and deploying new technologies, and they respond to practical, financial incentives much more effectively than a single, state-run utility whose wider mandate is to provide a public good. Households can also be considered as private sector participants, and their willingness and ability to invest in rooftop PV installations can play an important role in promoting renewable energy at grassroots level, a consideration underlying several European countries' popular practice of feed-in tariffs for private households with own renewables-based energy systems. A 
liberalized utility market with competing producers and providers of electricity (and potentially in the MENA context, of desalinated water) can further help promote greater renewables uptake with the attraction of cost savings - rather leading to increased costs - provided fuel input prices reflect economic costs and renewable energy sources compare favourably with conventional fossil fuels.

There many ways to allow private sector access to the utility sector: legislative change, already in place in a number of MENA countries, can encourage private-public partnerships and gradually allow for complete private ownership over production. Utility provision can remain in public hands, especially in countries where populations may expect the state to 'provide' electricity, but it may over time also be liberalized, in order to allow consumers free choice over providers. In addition to a stable political climate, key to the functioning of these initiatives is access to financial means via equity and debt, with a potentially critical role for government regulation in ensuring the private sector's needs for financial capital to invest in renewable (and other) energy projects are met by local banks and financial institutions. Renewables-based projects also have very specific needs, particularly during the initial R\&D and demonstration phases. The capital risk of renewables projects is high, and investors may require additional guarantees such as feed-in tariffs - these entail a rather more active fiscal role to be played by the state in promoting these technologies ${ }^{61}$ Agricultural banks, widespread in North Africa, could provide a possible model for investment in renewables-based projects, for example, in households wishing to invest in rooftop PV power. International financial bodies such as the World Bank, the International Financial Corporation (IFC), and the Islamic Development Bank (IDB), could also play a role, including the financing of more off-grid, rural electrification solutions. ${ }^{62}$ Islamic financial products such as sukuk financing have also been discussed as potential MENA-fit investment tools to promote renewable energy investment; they have been successfully used in Jordan and Morocco. ${ }^{63}$

\subsection{The economics of the second best: fiscal and regulatory incentives}

In the absence of feasible policymaking scope to reform domestic energy markets structurally, governments also have the choice to promote renewable energy via a different set of measures known as 'fiscal and regulatory incentives'. Some of these incentives may also be complementary to those strategies discussed above, or they may help achieve renewable targets in the short- and medium-term. The disadvantage of such fiscal and regulatory measures, however, is that they usually reinforce existing market distortions and aggravate them further through the introduction of yet more distortions aimed at 'fixing' the negative consequences of maintaining current market structures. These policy instruments usually entail an additional deadweight loss, which adds to the already burdensome cost of resource waste through inefficient market pricing mechanism for existing fuels. They will also probably require subsequent adjustment and revision, placing effective government policy at the heart of using these tools effectively. Regulatory and fiscal incentives are hence secondbest options, unlikely to resolve the problem, but possibly able to treat some of the symptoms.

\section{Regulatory incentives: Renewable energy targets}

Where renewable energy uptake is not promoted by clear economic incentives, national renewable targets can offer governments a particularly important policy instrument capable of sending signals to the economy and of opening the door for further, deployment-generating, policy incentives or quota systems. Renewable targets can be part of a wider energy market 'vision' to be promoted by government members among local industry and the private sector. This can help governments to communicate any applicable market reform more effectively to both population and industry, and importantly, also, to any domestic and international financial institutions that may be funding part of the new renewable energy capacity. Many MENA countries have adopted renewable energy targets during the 2000s, as shown in Box 1. 


\section{Box 1: Renewable energy targets in the MENA Region at End-2013}

\section{North Africa}

Algeria: $6 \%$ of electricity generation by $2015 ; 15 \%$ by $2020 ; 40 \%$ by 2030 , of which $37 \%$ is solar (PV and CSP) and $3 \%$ is wind

Libya: $3 \%$ of electricity generation by $2015 ; 7 \%$ by $2020 ; 10 \%$ by 2025

Morocco: $42 \%$ of installed power generation capacity by 2020

Tunisia: $11 \%$ of electricity generation by $2016 ; 25 \%$ by $2030 ; 16 \%$ of installed power capacity by $2016 ; 40 \%$ by 2030

\section{East Mediterranean}

Egypt: $20 \%$ of electricity generation by 2020 , of which $12 \%$ is wind

Israel: $5 \%$ of electricity generation by $2014 ; 10 \%$ by 2020

Jordan: $7 \%$ of primary energy by $2015 ; 10 \%$ by 2020

Lebanon: $12 \%$ of electrical and thermal energy by 2020

Palestine: $25 \%$ of energy from renewables by $2020 ; 10 \%$ (or at least $240 \mathrm{GWh}$ ) of electricity generation by 2020

Syria: $n / a$

\section{The Gulf States}

Bahrain: $5 \%$ by 2020

Iran: $\mathrm{n} / \mathrm{a}$

Iraq: $2 \%$ of electricity generation by 2016

Kuwait: $5 \%$ of electricity generation by $2015 ; 10 \%$ by 2020

Oman: $10 \%$ of electricity generation by 2020

Qatar: At least $2 \%$ of electricity generation from solar energy sources by 2020

Saudi Arabia: 50\% of electricity from non-hydrocarbon resources by 2032: $54 \mathrm{GW}$ from renewables (of which: 41GW from PV and CSP, 9GW wind, 3GW waste-to-energy, 1GW geothermal), 17.6GW from nuclear

UAE: Dubai: $5 \%$ of electricity by 2030 ; Abu Dhabi: $7 \%$ of electricity generation capacity by 2020

Yemen: $15 \%$ of electricity generation by 2025

Source: REN21/ISEP (2013); Author.

RES targets alone, however, are not sufficient to raise the share of renewable energy within any given country's energy mix. Despite fairly distributed targets across MENA economies, Figure 8 below illustrates that actual investment during the late 2000s came primarily from three countries: Morocco, Israel, and the UAE. A 2010 study comments, for instance, on the lack of comprehensive energy planning to follow up RES targets in the case of Abu Dhabi:

In the absence of a comprehensive planning document, Abu Dhabi has made several announcements that can be interpreted as parts of a new strategy that includes the promotion of renewable energies, such as the $7 \%$ renewable energy goal $\ldots$, the announcement to launch a solar rooftop programme, and the introduction of a smart metering system ... as a first step into an innovative demand side management system in 2011. Thus, while elements of a comprehensive strategy have been released, the document as a whole is still 

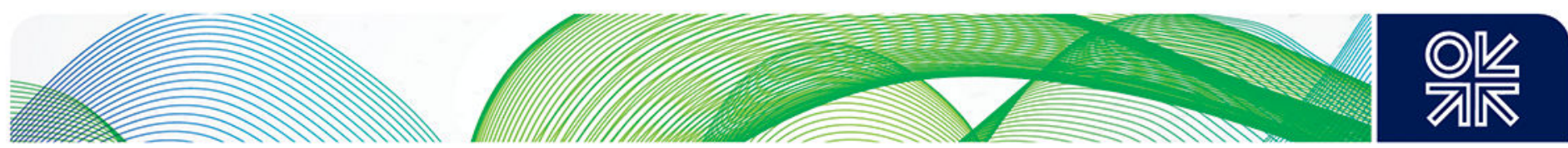

missing in spite of its public announcement in early 2009. This is also the case for details about funding schemes, tax deductions, and the height of premiums for renewable electricity or other tangible data that are vital for any substantial business plan. ${ }^{64}$

Similar observations could be made about other key hydrocarbon producers, such as Iran, Iraq, Kuwait, and Saudi Arabia. The latter's particularly ambitious targets - of generating some 50 per cent of its energy needs by 2032 using non-hydrocarbon resources - have so far been matched by no dedicated national policy framework, no national energy strategy, and RES investments by 2012 which have barely scratched the 100 million dollar mark. ${ }^{65}$ In stark contrast, Morocco with a per capita GDP several times below that of Saudi Arabia, invested over US\$1.89 billion into renewable energy projects in 2012 alone, indicating vastly diverging levels of political and economic interest in the pursuit of these technologies. ${ }^{66}$

Figure 8: Trends in Renewable Energy Investment in the MENA Region, 2009-2012

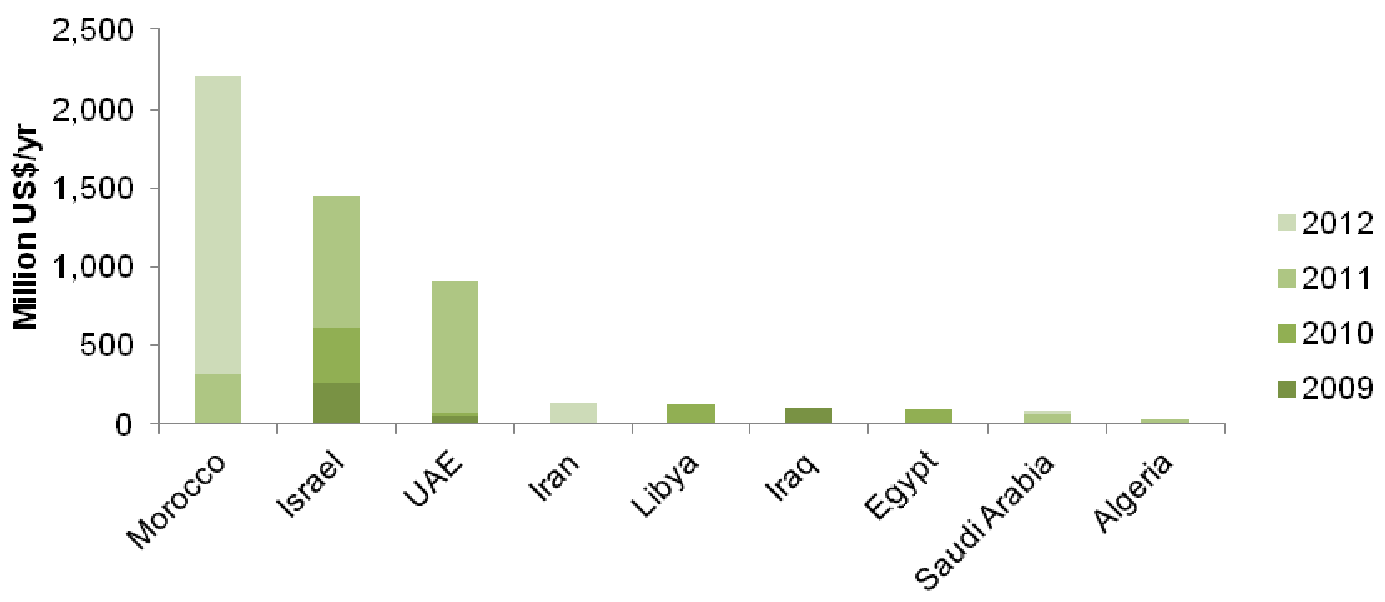

Source: REN21/MOFA/IRENA (2013).

Static, and possibly arbitrary, RES targets may also harm the cause of renewables by further concealing the cost advantage that renewable energy may have over fossil fuels when actual economic costs are taken into consideration. National production quotas, or large prestige projects aimed primarily at deploying renewable energy at any cost, will help reinforce the message that renewables are an expensive technology built only due to political will, or in reflection of elusive ecological considerations. Harvesting the benefits of renewable energy in the MENA region will thus require significantly more sophisticated policies in the medium- and long-term than merely the presence of RES targets themselves.

Fiscal incentives: carbon taxes, tax benefits, feed-in tariffs

Policies involving fiscal incentives are widely used in European and North American markets to raise the attractiveness of investment into renewable energy. Typical forms of such policies include: punitive schemes such as carbon taxes that 'punish' fossil fuel use in power generation; and positive reward schemes, such as feed-in tariffs that guarantee profits to renewable energy producers and reduce the cost of renewables-based electricity to final consumers. Punitive schemes can be revenue-neutral, for instance where governments use savings made and re-channel them in different forms - such as cash transfers or cross-subsidies - to producers of alternative energy. Positive reward schemes, on the other hand, require the application of government funds to the initial capital investment into renewable energy technologies - such additional funding must be present at the start of the project. Both schemes offer benefits but also entail some serious challenges. 
Carbon taxes. A typical measure in Europe and North America, used to promote renewable energy uptake by power producers and households, has been the imposition of a carbon tax. This artificially raises the price of carbon-intensive fuels, such as oil and coal, and rewards, to some extent, the use of natural gas, and to a greater extent renewable energy, thus significantly reducing the cost attractiveness of oil and coal for power producers. ${ }^{67}$ Putting carbon taxes into practice in the MENA region would be a delicate task, and one where, in any case, a more obvious first step would be the reform of energy pricing structures. Even where such a solution is deemed feasible once pricing structures have been reformed in the first place, carbon taxes raise important questions over access in developing countries - this includes the MENA region's large number of medium income countries with significant populations below the poverty line. Whether, by contrast, they are deemed practical concepts in some of the MENA region's large, high-income oil and gas producers, such as Kuwait, the UAE, and Qatar, is a separate question; the large share of these countries' industrial base taken up by energy-intensive activities renders punitive carbon tax schemes arguably impractical for these economies.

Tax benefits and carbon credits. Positive tax credits, and tax exemptions for RES projects, offer MENA governments the reverse of such measures as carbon taxes. However, while they are probably more popular politically, they are also economically more wasteful. As a policy instrument, they may also not apply to MENA countries, such as Kuwait, which have no income tax on national businesses. ${ }^{68}$ Tax benefits are complex fiscal measures that require a certain degree of government control and financial transparency of businesses, which are prone to abuse in weak administrative systems. Chances are hence high for the abuse of such policy instruments in countries with existing cleavages between different population groups. Where applied sensibly however, tax incentives may help generate genuine investment opportunities for new companies.

Some proponents of structural energy pricing reform in the MENA economies have also proposed the introduction of a carbon credit system (also variously termed quota schemes or tradable green certificates) that rewards power producers on an emissions basis, encouraging both investment in renewables projects and energy efficiency upgrades. ${ }^{69}$ Such carbon trading schemes may be particularly attractive if applied in the context of wider energy efficiency planning, and regulatory efforts by governments in order to raise efficiency and emissions standards, both at residential and industrial level. Carbon credits are an option in fully-functioning, and liberalized power markets in which different power providers compete with each other on a cost basis - this makes carbon credits a long-term policy option. Electricity tariffs that will enable all utilities to recover costs and make moderate profits would be required for any carbon credit system to work, hence tying this scheme back to a wider electricity pricing reform.

Feed-in tariffs (FITs). FITs reward renewable energy projects and ensure cost recovery plus socially acceptable profit margins, and can significantly contribute to rapid uptake in RES production in the short- and medium-term. Feed-in tariffs guarantee to the producer a fixed purchase price, based on the cost of renewable energy generation under time-set contracts (typically 15-25 years), alongside grid-access. ${ }^{70}$ Some European countries have also encouraged private households to feed surplus electricity production from their own rooftop installations into the grid, further improving the economics of private household investment in self-supplying technology (net-metering) - a system Abu Dhabi has reportedly been planning. ${ }^{71}$ Quota-based systems are a likely model for many MENA economies; they work under the same principle as feed-in tariffs but apply to predefined quantities of energy production based on renewables inputs. This is purchased under predefined contract provisions by other utilities or the public electricity provider under a single-buyer scheme ${ }^{72}$ Auctions, or other forms

67 EEA $(2001,53)$

68 For an overview over Kuwait's corporate tax code, see Ernst and Young, ESIA and Eversheds $(2013,19)$.

69 For a general discussion of the concept, see European Environment Agency (2001, 29). For a MENA-based context, see $\operatorname{OECD}(2013,11)$.

70 OECD $(2013,55)$

71 IEA (2011a, 79); EEA (2001, 8); OECD $(2013,59)$. For Abu Dhabi, see Kumetat $(2012,192)$

$72 \operatorname{OECD}(2013,60)$ 
of competitive bidding, can be used to contract producers to a single buyer utility which pays a predefined guaranteed price for a set number of years.

The transaction cost for household-based FIT schemes will be higher than for utility-sized installations, making this option attractive primarily for higher income economies such as those of the GCC. At utility level, feed-in tariffs will typically result in higher prices for electricity than the spot level under a liberalized market, and in the MENA context (for as long as domestic electricity prices remain administered) feed-in tariffs will involve a substantial rise in direct producer subsidies. Feed-in tariff systems may thus be too costly for MENA countries with existing fiscal shortcomings, but offer an opportunity for higher-income economies such as the GCC states.

\subsection{Integrating renewable energy within national energy strategies}

Using renewable energy to achieve primary objectives serving the wider social benefit can be another way of rendering new technologies more acceptable. Exploiting the many positive externalities entail by renewables - many of these remain external to formal pricing and thus require government intervention to be utilized - can further the economic value of renewable energy sources for the national economy. But care is needed; not all promises of positive spill-over effects are realistic in the national context of individual countries, nor can renewables offer a ready-made, stand-alone solution to other, fundamental economic problems - such as missing job opportunities and poverty - as some regional government plans may suggest. Understanding the options that renewable energy offers to the MENA region will thus require considerable country-level work beyond the more general discussion below.

\section{Exporting renewable energy to the Middle East and Europe}

Cross-regional electricity trade may be one of the most effective ways to make renewable energy investments more profitable and attractive to a growing number of investors in the MENA region. Cross-border electricity trade broadens the market for electricity production, creating opportunities for economies of scale in scope - an important potential cost factor for investors in new large projects. Cross-regional trade schemes that export electricity into higher-value markets, such as Europe, also provide access to markets where current market prices may already be high enough to support the price of renewables, as in the case of close-neighbour countries such as Morocco and Spain, and the Levant and Turkey. ${ }^{73}$ IEA figures currently put the cost of firm and dispatchable electricity in North Africa at currently around US $\$ 210 / \mathrm{MWh}$, although costs are expected to fall to less than $\$ 150 / \mathrm{MWh}$ by 2020 - with assessed transit costs to Southern Europe of between $\$ 20-\$ 40 / \mathrm{MWh}$ of electricity. The IEA sees North African solar power as 'an attractive way to comply with current and future renewable obligations of European Union countries'. ${ }^{74}$ Two of the MENA region's (so far) largest solar power plants have been tied to precisely this trading advantage: the EU-sponsored Mediterranean Solar Plant (MSP) and the private (though with strong support from European, American, and MENA policymakers) solar industry initiative Desertec; both are focused on producing solar power in North Africa and exporting it to Europe.

Launched in 2008, the MSP forms part of the six initiatives of the Union for the Mediterranean (UfM), an outcome of the preceding Barcelona process. Part of the UfM's core objectives is: the management of water and energy resources, the addressing of environmental challenges, and the promotion of wider economic development across the Mediterranean basin. The MSP was devised as a key initiative aimed at securing Mediterranean energy supply over the long term, creating technology centres of excellence, as well as providing the region with potential new export industries. The core objective of the initiative remains the construction of $20 \mathrm{GW}$ of electricity generation capacity, from solar and other renewable energy sources, in the Southern and East Mediterranean by $2020 .{ }^{75}$ Part of the plan also includes the gradual interconnection of the southern, eastern, and

73 Jablonski et al. (2012); Boubaker (2012); Karakosta and Psarras (2013); Supersbergera and Fuehrer (2011). 
northern Mediterranean countries to form one large integrated Mediterranean grid, under which renewable electricity from North Africa and eventually the East Mediterranean could be exported to Europe. $^{76}$

Desertec was conceived by a group of German industry associates and launched in 2009 as a private industrial initiative which aimed to create large-scale solar and wind energy farms across the South and East Mediterranean (including the Sahara desert) to supply both domestic markets and the European market with renewable energy. The eventual objective was for Southern Mediterranean countries to produce enough renewable power to supply up to 15 per cent of Europe's electricity needs by 2050, in addition to meeting a substantial proportion of producing countries' domestic energy needs. Like the MSP, Desertec involved plans for the creation of an integrated north-south Mediterranean power grid able to transport electricity across the three shores. ${ }^{77}$ Both projects rest on the favourable economies of North African solar irradiation, versus a premium price for electricity on the Spanish market of (in 2010) around Euro cents $27 / \mathrm{kWh}$, deemed sufficiently high to support largescale PV installation costs in North Africa. ${ }^{78}$

Not all sides have embraced the economics (and political aspects) of such cross-border projects. While supporters of MSP and Desertec-style projects suggest solar projects may soon shift the balance of energy power in Europe away from the Gulf towards solar North Africa, ${ }^{79}$ its opponents have questioned the security of European electricity demand for North African solar power, as well as the underlying 'mass production'-style economics of such projects; Desertec in particular has thus far been seen by some of its critics as a failure. ${ }^{80}$ Some argue that the North African region's status may be reduced to that of a guinea pig for large-scale investment in renewable energy production, while Europe assumes the role of the region's solar colonizer ${ }^{81}$ Others suggest that initiatives such as the MSP may face uncertain commercial prospects, but that they have helped local economies move ahead with parallel indigenous solar projects that have benefited from newly available financing options and public promotion of the two larger cross-regional initiatives. ${ }^{82}$

Inside the MENA region, significant additional, cross-regional trading potential exists, particularly where the necessary infrastructure is already largely in place - the GCC states, parts of the East Mediterranean, as well as the Maghreb countries, already possess interconnected grids that would technically be able to support systematic intra-regional electricity trade, though substantial electricity trade has, with the partial exception of Morocco and Algeria, not yet been forthcoming. ${ }^{83}$ Occasional neighbourly electricity trade also already exists, for instance between Morocco and Algeria, Iran and Iraq and some of their respective neighbours, and the GCC states. In 2013 Egypt and Saudi Arabia renewed their plans to connect their power grids to allow for electricity trade, utilizing differences in peak demand times. ${ }^{84}$ Making more systematic and more effective use of these connections will require further political will, as well as utility market reforms - such as adjusted power pricing rules and the creation of a regional, competitive electricity market - that will render regional trade in electricity commercially attractive. ${ }^{85}$

\section{Making use of 'green growth' opportunities}

Renewable energy is frequently portrayed as a catalyst for wider economic benefits such as industrial development around 'green' technology clusters, and the developing countries' all-important concern

\footnotetext{
76 EU/R\&L (2010, 18-29).

77 Dii (2012). For a conceptual description of Desertec, see www.desertec.org/concept/.

78 Trieba et al $(2012,309)$. Spanish electricity prices have since come down but continue to exceed the MENA region's electricity price levels greatly, with the exception of the high-price market of Morocco.

79 Marktanner and Salman $(2011,4479)$.

80 For instance, see most recent reporting: EurActive (2013).

81 Marktanner and Salman (2011, 4480); Ummel and Wheeler (2008).

82 For instance, see Brydon et al. (2013); Hafner et al. (2012).

83 El-Katiri (2011, 24-9) explains the various regulatory and market hurdles in the case of the GCC Interconnection Grid.

84 Saudi Gazette (2013).

85 For a detailed discussion in the GCC context, see El-Katiri (2011).
} 
of skilled job creation. The frequently emphasized advantage of renewable energy technology lies, to some extent, in the relative ease of technology transfer between producing and newly producing countries, the comparatively low capital-intensity of renewable technologies vis-à-vis other energy industries, and thus in the significant opportunities for developing countries to set up their own manufacturing and R\&D industries ${ }^{86}$ On the other hand, it is frequently asserted that:

... compared to fossil fuel power plants, renewable energy generates more jobs per unit of installed capacity, per unit of power generated and per dollar invested. ${ }^{87}$

A 2010 World Bank study indeed suggests that nearly 50,000 new local jobs for manufacturing components could be created by 2025, if there were to be strong development of CSP components factories in five MENA economies (Algeria, Egypt, Jordan, Morocco, and Tunisia) alone. ${ }^{88}$ Marktanner et al. point to similar conclusions in the case of North Africa, comparing renewable with nuclear energy opportunities:

Closely related to the aspect of technology transfer is the question of forward and backward linkages ... The construction of a network of renewable energies across North Africa and the Middle East will likely spill over economic activities into areas such as manufacturing, construction, transportation, research, and service industries. $^{89}$

There are, nevertheless, strong indications to caution the level of expectation surrounding 'green' growth opportunities in the MENA region - not least in view of the vast potential for such supposed, positive side-effects to turn into a major fiscal drain, and hence an economic trap rather than an opportunity. Renewable energy in the MENA region is frequently portrayed as offering the region similar industrial opportunities as to European and Asian countries, despite apparent disparities in both the economic and temporal context. ${ }^{90}$ Many observers have highlighted issues surrounding the availability of skilled labour in countries in the MENA region: inadequate skills among the national workforce, particularly in highly-skilled technology development jobs; and the unwillingness of national labour in some MENA countries, such as the GCC states, to work in the kind of labour-intensive manufacturing element of the value chain that would probably generate the most productive work. ${ }^{91}$ While both these problems are less significant in North Africa and, to some extent, the Levant, the region as a whole also suffers from significant disadvantages, in contrast to Asian manufacturers, in areas such as labour costs; such considerations raise the question whether local, MENA-based manufacturing industries can indeed generate real economic value and manufacture technology products that would be price-competitive internationally. ${ }^{92}$

An outlier position in this respect is held by Israel, which has so far been the only country in the MENA region that has benefited significantly from government policies promoting the establishment of an indigenous solar technology industry. Due to energy security considerations Israel has, from early on, placed a premium on all energy technologies that reduce the country's exposure to energy imports. Israeli policymakers established a mandate for solar water heating technologies as early as 1980 , the first country in the world to do so. ${ }^{93}$ While remaining a small-scale producer of solar power by international comparison, policy incentives turned Israel into a fast-growing market for solar heating technologies, making it the world's second-largest user of solar water heating, in per capita terms, after Cyprus. Israeli solar heat companies are, by now, considered leaders in their field, having

86 OECD $(2013,38)$. See also ILO (2008), El-Husseini et al. (2009).

87 UNEP (2008). See also Lund (2009).

88 World Bank/ESMAP (2011). For further discussion and simulations, see van der Zwaan et al. (2013). Simulating the effect of Moroccan RES plans under a baseline scenario, a 2010 study confirms the potential for trickle-down effects of renewable energy targets into the Moroccan economy, including the creation of some 269,000 jobs and a $1.21 \%$ share in GDP by 2040 . De Arce et al. (2010, 341).

89 Marktanner and Salman (2011).

90 IEA (2011a, 69); OECD (2011)

91 For instance, see Himri (2009, 1590); Patlitzianas et al (2006); Kumetat (2012, 201-3).

92 Mills (2013).

93 REN21 $(2011,59)$. 
found comfortable niches for themselves on the manufacturing market, and generating sound profits while venturing increasingly into other solar technologies, creating valuable skilled jobs. ${ }^{94}$

\section{Institution-building and research}

Promoting the creation of self-governing industry bodies and interest groups, and of regional research centres in areas such as renewable energy can make a valuable contribution to the promotion of renewable technology across MENA countries. Self-governing bodies can also help de-politicize renewable energy targets if the indigenous industry rather than the government proposes technology deployment and new green projects. R\&D initiatives can help foster national capacity building, helping generate knowledge and understanding of the benefits of renewable energy as well as of those structural reforms deemed politically unpopular at present. Successful deployment of RES is often conditional on:

- $\quad$ sufficient resources being dedicated to the initial development process of renewable technologies within the local context;

- $\quad$ training and education, including of those able to drive technology development and deployment; and

- $\quad$ public support of R\&D activities surrounding the energy sector, including activities that can help shape policies suitable for the local context as part of wider sectoral reform along the energy value chain. ${ }^{95}$

The MENA region has seen a proliferation of renewable and wider energy-related R\&D activity as well as business associations throughout the 2000s. These include the International Renewable Energy Agency (IRENA) based in Abu Dhabi, ${ }^{96}$ and specialized industry bodies such as the Emirates Solar Industry Association (ESIA), recently renamed Middle East Solar Industry Association (MESIA). ${ }^{97}$ Large industrial complexes with adjacent research facilities have been created in Abu Dhabi - Masdar City ${ }^{98}$ - and in Saudi Arabia - the King Abdullah City for Atomic and Renewable Energy (K.A.CARE) ${ }^{99}$ while the Cairo-based Regional Center for Renewable Energy and Energy Efficiency (RCREEE) $^{100}$ and the EU-GCC Clean Energy Network ${ }^{101}$ are initiatives which promote MENA-based research and investment into energy efficiency. Meanwhile, one of the MENA region's oldest research centres for national renewable energy development can be found in Kuwait, where the Kuwait Institute for Scientific Research (KISR) was founded back in the 1970s, partly to conduct research in the area of renewable energy. ${ }^{102}$ Once again, the availability of funding for such activities must be a means to an end, not an end in itself, in order to ensure value for money is produced where such institutions are publically funded.

\section{Renewable energy and rural electrification}

A frequently overlooked contribution that renewable energy can make within the energy markets of many developing countries is in the electrification of remote, rural regions. The UN, in 2011, expressed its concern that:

... over three billion people in developing countries rely on traditional biomass for cooking and heating, that one and a half billion people are without electricity and that, even when energy services are available, millions of poor people are unable to pay for them. ${ }^{103}$

\footnotetext{
94 IRENA (2013c, 18).

95 For a discussion, see Mizuno (2010); IEA (2011a).

96 IRENA's website can be found at www.irena.org/home/index.aspx?PriMenuID=12\&mnu=Pri.

97 MESIA's website can be found at www.mesia.com.

98 Masdar city's website can be found at http://masdarcity.ae/en/.

99 K.A.CARE's website is available at www.kacare.gov.sa.

100 RCEEEE's website can be found at www.rcreee.org.

101 The EU-GCC's Clean Energy Network's website can be found at www.eugcc-cleanergy.net.

102 KISR's website is available at www.kisr.edu.kw.

103 UN (2011).
} 

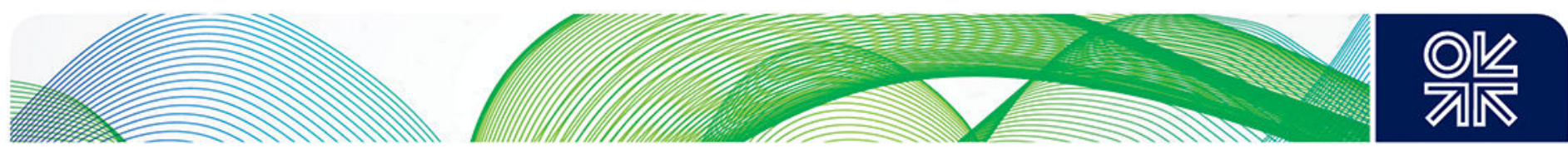

The gravity of the problem, which IEA officials have branded as 'shameful and unacceptable" ${ }^{104}$ is by no means unknown in MENA countries, despite the region's overall hydrocarbon wealth; a recent study shows that around 20 million people in the MENA region live without access to even basic levels of electricity; this includes one million Moroccans, 1.4 million Syrians, 1 million Iranians, more than 4 million Iraqis, and more than 14 million Yemenis. ${ }^{105}$

Historically, the primary market for solar systems in developing countries has been for off-grid applications, mainly home PV electricity, and water rooftop heating systems. ${ }^{106}$ In remote geographical areas, solar systems in particular - and once installed - provide low-cost electricity with considerably lower pollution than established alternatives such as diesel and kerosene generators, thereby contributing to rural health and wellbeing. ${ }^{107} \mathrm{~A}$ French development report summarizes the advantages of local renewable generation capacity, pointing to the many benefits of renewablesbased projects beyond their advantages from a climatic point of view:

The use of renewable energy sources therefore addresses less the issue of climate constraints than financial considerations: rural electrification based on renewable energy enables local resources to be used to best advantage while remaining free from the price volatility of fossil energy and the extra costs associated with its transport to isolated areas. Accordingly, in many rural regions, recourse to low-carbon solutions is an economically rational way of enabling poor households to gain access to a quality electricity service. ${ }^{108}$

Limitations to the scope and service quality of local versus grid-based solutions apply. Morocco's Programme d'Électrification Rurale Global (PERG) has facilitated electricity access for more than a million households since the 1990s, but the services of many local generators, including photovoltaic, diesel, and wind, provide an inferior (shorter operating hours and less reliable access) service to that of grid-based access. ${ }^{109}$ Many village-based minigrid solutions in Yemen report similar failings, thus exposing households to continued electricity outages on a daily basis. The most severe consequence of continuing volatile electricity supply in these villages remains the inability to store spoilable medicines, to obtain light when needed at the time of medical emergencies and to operate basic medical electrical devices. ${ }^{110}$ This means that in the most effective cases, renewable technologies are combined with conventional fuel technologies, such as diesel generators, thus providing a significantly more reliable supply, and helping to displace inferior technologies such as kerosene lamps and biomass heating. ${ }^{11}$

Several MENA countries which are affected severely by energy poverty have run successful rural electrification programmes based partially on renewable energy inputs such as solar and wind technologies. Morocco's PERG, first launched in 1996 when rural electrification rates were estimated to be as low as 18 per cent, connected, over a period of fifteen years, more than 35,000 villages, including some 1.9 million rural households, driving up rural electrification rates to 97 per cent by $2009 .{ }^{112}$ Renewables-based electricity systems formed an important part of the government's strategy to bring energy independence to those rural communities that could not be cost-effectively linked to Morocco's national grid. The choice of technology for such communities was based on an initial assessment related to local geographical and climatic factors that would favour specific technologies. ${ }^{113}$ Jordan gained similarly positive results following its 2002 launch of a rural

\footnotetext{
104 IEA/UNDP/UNIDO $(2010,8)$.

105 El-Katiri (2014 forthcoming)

106 Hoffmann (2006); Moner-Girona et al. (2006).

107 World Bank $(2008,47)$. See also Karekezi (2002).

108 Raspaud $(2012,3)$.

109 Raspaud $(2012,3)$; This fact has also been observed by the author's own observations in rural Morocco.

110 World Bank $(2005,32)$.

111 IRENA (2013c, 19); Müller, Brown and Ölz $(2011,16)$

112 Agence Française de Développement (2013).

113 For a detailed account, see El-Katiri (2014 forthcoming)
} 
photovoltaic (PV) electrification programme, aimed at improving both access to electricity and quality of life for rural electricity users. ${ }^{114}$

In the case of rural electrification programmes, conventional fuel-based self-generators and smallscale village-based systems rely on being able to repair the system - such knowledge is local and easily accessible even at village level. By contrast, many renewables deployment programmes at the rural level have, in the past, overlooked the necessity of sufficiently training local people in the maintenance and repair of, mainly, PV installations. This has led to supply disruptions - perceived technology risk - which may lead local communities to prefer those types of technologies they are easily able to master. The technical know-how for simple PV systems is, in principle, easily transferrable, implying the existence of ample opportunities to help empower rural communities to maintain their PV systems themselves and hence to remain self-sufficient once the initial installation has been made. However, frequent lack of experience and absence of policy emphasis on local training have, in the past, limited the uptake of local know-how and skills, while publically or aid(rather than privately) funded initiatives often entail no economic incentives for local stakeholders to maintain PV infrastructure, particularly where PV-powered electricity is free for users, and hence generates no local commercial interest. Past experience suggests that such issues highlight key weaknesses that have reduced local acceptability of rural PV uptake, regarding it as an imposed, impractical technology, and have led to continued reliance on 'known' energy systems, despite economic and health-related drawbacks. ${ }^{115}$

\section{Conclusion}

The MENA region has, in the past, been frequently overlooked as a market for renewable energy, a fact that is reflected in the relatively recent shift in policy attention throughout the region towards the more systematic incentivizing of renewable energy deployment. This study has shown that the potential for renewables technology (such as solar and wind energy) to provide cost-effective solutions for the existing energy mix in many MENA economies differs from that seen in the highly subsidized renewables markets in Europe and North America, if full economic costs for the MENA region's existing domestic energy mix are taken into account. In this sense, the MENA region could indeed be illustrative of a structural pattern among developing economies facing similar climatic conditions; many such economies face similarly administered domestic energy markets, in which distorted prices for fossil fuels and electricity conceal a real economic opportunity for alternative energy which is far beyond its commercial value in many industrialized countries.

In the MENA region, the case is particularly strong in the case of solar technologies, due to regional climatic conditions that can be found in many parts of the global South; while wind technology offers an existing cost-competitive technology option, with significant cost saving potential vis-à-vis conventional fossil fuels, to some parts of the region. The case is likely to be even stronger once longterm social benefits - so-called 'positive externalities' - such as lowered environmental pollution, rising quality of life, and clean rural electricity supply in those MENA countries with sizeable rural lowincome households, are demonstrated. While renewable energy targets in Western, industrialized economies are frequently associated with emissions targeting and climate change considerations, many developing economies - the MENA region being an important case in point - may actually consider renewable energy technologies as an economic solution for the supply of their rapidly expanding domestic energy markets.

Raising the share of renewable energy in the MENA region in the time period up to the 2030s will, nevertheless, require the involvement of highly individualized policy solutions based on each MENA economy, and these are likely to entail some form of electricity market restructuring. Under current market mechanisms - which include a lack of competition between electricity producers and a mere

\footnotetext{
114 Al-Soud and Hrayshat (2004).

115 Martinot et al. (2002, 313); The author is grateful to David Robinson, discussion with whom has additionally contributed to these conclusions.
} 
infant private sector inside power generation (hampered by decades of public utility provision) - the pricing mechanisms of conventional fossil fuels and of electricity will be unable to render transparent those cost advantages that some renewable energy technologies are likely to offer to the region. This is also true in the case of the MENA's oil and gas producers, who will need to consider their opportunity cost, rather than the mere long-run cost of producing fossil fuels, in order to see the favourable economics of renewable energy at work.

The most important element in assessing and realizing any cost advantage of renewable energy (as well as nuclear power) vis-à-vis fossil fuels to the MENA region's economy will undeniably require the reform of their domestic energy markets, particularly their pricing schemes, alongside greater private access at utility production level under a more liberalized market-based system. The political fragility of the MENA region, following the political protests that have swept across the region as part of the Arab Spring since early 2010, undoubtedly complicates such (likely) unpopular market reform; however, there are mechanisms at hand that should help these economies move towards marketbased utility systems. These include the option of redistributing savings made via dedicated social safety systems (thereby strengthening welfare while reducing economic waste), or by coupling energy pricing reforms to universal distributive systems such as resource-based citizens' dividends, similar to the Alaskan, Norwegian, or Iranian models (imperfect as they may be). In this way, deadweight loss and resource waste would be reduced, saving valuable funds for better use towards alleviating poverty, and truly allowing all citizens to benefit from countries' resource wealth. If renewable energy were to be a triggering factor in the consideration of such price reforms, their value for the MENA economies would undoubtedly exceed that of any other policy target.

The use of fiscal tools in order to facilitate renewables-based investments, referred to above as second-best options, offer one potential path into a higher rate of renewables production in the MENA region; they can be interim measures or be combined with wider-reaching market reform, or used as stand-alone mechanisms in an attempt to balance out existing market distortions - similar to their use in other markets in Europe and North America. Many fiscal tools, however, come with their own costs: they are essentially distortions introduced into the economy in order to fix other distortions. Such a treatment of symptoms, rather than of the root cause, may indeed exceed the fiscal means of less wealthy economies, rendering active fiscal support mechanisms - such as reward schemes and tax incentives for 'green' projects - an unaffordable luxury indeed for those MENA economies that already struggle with imported energy prices today. This may very well explain why imported fiscal tools to encourage seemingly renewable technologies in developing countries may not actually work and suggest that energy market reform may be the actual victory tool in promoting renewables in developing country contexts.

Change, including in the areas of energy and technology, is frequently said to be driven either by desperation, or by inspiration. ${ }^{116}$ In the Middle East and North Africa, both factors appear to have been mostly absent from national policymaking agendas for many decades. Rising global prices for oil, and hence the rising gap in the value of energy between domestic MENA markets and internationally, have nevertheless changed the rules of the game for both fossil fuel exporters and importers inside the MENA region. And so, it may be ironically true that heightened oil prices drive a gradual shift inside MENA economies towards a wider array of regional energy sources based on their economic value; and to the adaptation of energy market mechanisms that reflect costs and help MENA economies build long-term sustainable welfare systems that create and preserve, rather than destroy, value. 


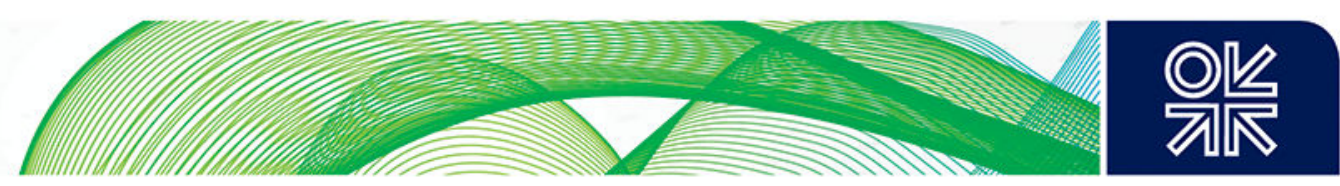

\section{Bibliography}

Agence Française de Développement (2013). 'Le Programme d'électrification rurale global (PERG) au Maroc'. Available online at www.afd.fr/home/AFD/L-AFD-s-engage/rioplus20/projetsrio20/electrification-maroc (retrieved July 2013).

Ahn, E.H., Arce, J. (2009). 'Solar Power as "Peaker" Power - The impact of the California Energy Commission's Chula Vista Power Plant Decision on San Francisco and the State', Brightline Defense Project, 10 September.

Aissaoui, A. (2013). 'Between a Rock and a Hard Place: Egypt's New Natural Gas Supply Policy', Middle East Economic Survey, 56:11, 15 March 2013

Al-Ghadd (2011). 'As-Sa'udiyyah ta'tazim tasdir lil-mamlaka bi-asa'ar tafdhiliyyah', ['Saudi Arabia plans to export to the Kingdom under preferential prices'], Al-Ghadd, 31 July 2011.

Al Moneef (2006). The Contribution of the Oil Sector to Arab Economic Development, OFID Pamphlet Series No. 34, Vienna: OPEC Fund for International Development.

Al-Karaghouli, A. (2007). Current Status of Renewable Energies in the Middle East and North African Region, United Nations Environment Programme, Regional Office for West Asia (UNEP/ROWA).

Ar-Ra'ii (2013). 'Al-'Iraq tasta'nif tasdhir an-naft bi-sa'r tafdhili' ('Iraq aim for oil exports at preferential prices'), Ar-Ra'ii, 17 December 2013.

Al-Saleh, Y.M., Upham, P., and Malik, K. (2008). 'Renewable Energy Scenarios for the Kingdom of Saudi Arabia', Tyndall Working Paper 125, October 2008, Tyndall Centre for Climate Change.

Al-Sharq Al-Awsat (2013). 'Irtifaa asaar al-naft jaaidu dhaght aala maliyyah al-hukumah almaghribiyyah', Al-Sharq Al-Awsat, 30 August 2013.

Al-Soud, M.S. and Hrayshat, E.S. (2004). 'Rural photovoltaic electrification program in Jordan', Renewable and Sustainable Energy Reviews, 8 (2004) 593-8.

Alnuaim, S. (2013). 'Saudi Arabia's one more go at a national energy strategy', Saudi Gazette, 29 September 2013.

Arab Union of Electricity (2012). Al-Tarifat Al-Kahraba'iyah fi-I Watan al-Arabi ['Electricity Tariffs in the Arab World', in Arabic], Amman: Arab Union of Electricity.

Bazilian, M., Roques, F. (2008). 'Introduction: Analytical Approaches to Quantify and Value Fuel Mix Diversity', in: Analytical Methods for Energy Diversity \& Security, Elsevier, Oxford, xxv-xlii.

Beck, F. and Martinot, E. (2004). 'Renewable Energy Policies and Barriers'. in: Cleveland, C. (2004 ed.), Encyclopedia of Energy, Volume 5, San Diego: Academic Press/Elsevier Science, 36583.

Birdsall, N. and Subramanian, A. (2009). 'Energy Needs and Efficiency, Not Emissions: Re-framing the Climate Change Narrative', Working Paper 187, Center for Global Development.

Bloomberg (2012). 'Saudi Arabia May Become Oil Importer by 2030, Citigroup Says', Bloomberg, 4 September 2012.

BNEF (2011). Sun Sets on Oil for Gulf Power Generation, White Paper, Bloomberg New Energy Finance, 19 January 2011.

Boubaker, K. (2012). 'Renewable energy in upper North Africa: Present versus 2025-horizon perspectives optimization using a Data Envelopment Analysis (DEA) framework', Renewable Energy, 43 (2012) 364e369.

BP (2013). Statistical Review of World Energy 2013, Available online at www.bp.com/en/global/corporate/about-bp/statistical-review-of-world-energy-2013.html (retrieved November 2013).

Branker, K., Pathak, M.J.M., and Pearce, J.M., (2011). 'A review of solar photovoltaic levelized cost of electricity', Renewable and Sustainable Energy Reviews, 15, 4470-82. 
Brown, A., Mueller, S., and DoBrotkova, Z. (2011). 'Renewable Energy Markets and Prospects by Technology', Information Paper, International Energy Agency, Paris: IEA.

Brydon, J., Riahi, L., and Zissler, R. (2013). MENA Renewables Status Report, REN21/IRENA/UAE, Directorate of Energy and Climate Change.

CCC (2011). The Renewable Energy Review, Committee on Climate Change, London. Available online at www.theccc.org.uk/publication/the-renewable-energy-review/ (retrieved November 2013).

Cherubini, F. et al. (2009). 'Energy- and greenhouse gas-based LCA of biofuel and bioenergy systems: Key issues, ranges and recommendations', Resources, Conservation and Recycling, Vol. 53, Elsevier, Amsterdam, 434-47.

Ciorbaa, U., Paulib, F., and Menna, P. (2004). 'Technical and economical analysis of an induced demand in the photovoltaic sector', Energy Policy, 32 (2004), 949-960.

Danish Energy Agency (2011). Energy Statistics 2011, Danish Energy Agency. Available online at www.ens.dk/sites/ens.dk/files/info/facts-figures/energy-statistics-indicators-energyefficiency/annual-energy-statistics//Energy\%20Statistics\%202011.pdf (accessed September 2013) (retrieved August 2013).

Darbouche, H., El-Katiri, L. and Fattouh, B. (2012). 'East Mediterranean Gas: What Kind of Game Changer?', Working Paper NG 71, Oxford Institute for Energy Studies, December 2012.

Darling, S.B., You, F., Veselka, T., and Velosa, A. (2011). 'Assumptions and the levelized cost of energy for photovoltaics', Energy and Environmental Science, 4, 3133-9, January.

De Arce, R., Mahia, R., Medina, E., and Escribano, G. (2010). 'A simulation of the economic impact of renewable energy development in Morocco', Energy Policy, 46 (2012) 335-45.

De Moor, A. and Calamai, P. (1997). Subsidizing Unsustainable Development, Earth Council and the Institute for Research on Public Expenditure.

Dehghan, A.A. (2011). 'Status and potentials of renewable energies in Yazd Province-Iran', Renewable and Sustainable Energy Reviews, 15 (2011)m 1491-6.

Dii (2012). 2050 Desert Power. The Case for Desert Power, Executive Summary, Dii GmbH, Available online at www.dii-eumena.com/fileadmin/flippingbooks/dp2050 exec sum engl web.pdf (retrieved July 2013)

DLR (2005). Concentrating Solar Power for the Mediterranean Region, A study commissioned by Federal Ministry for the Environment, Nature Conservation and Nuclear Safety Germany, Stuttgart: Deutsches Zentrum für Luft- und Raumfahrt e.V.

EIA (2013). International Energy Statistics, US Energy Information Administration. Available online at www.eia.gov/cfapps/ipdbproject/IEDIndex3.cfm\# (retrieved November 2013).

El Fadel, M., Rachid, G., El-Samra, R., Bou Boutros, G., and Hashisho, J. (2013). 'Emissions reduction and economic implications of renewable energy market penetration of power generation for residential consumption in the MENA region', Energy Policy, 52, 618-27.

El-Husseini, I., Fayad, W., El Sayed, T., Zywietz, D. (2009). 'A New Source of Power. The Potential for Renewable Energy in the MENA Region' Booz \& Co Perspective, available at http://www.booz.com/media/file/A New Source of Power.pdf (retrieved November 2013).

El-Katiri, L. (2011). 'Interlinking the Arab Gulf: Opportunities and Challenges of GCC Electricity Market Cooperation', OIES Research Paper, EL8, Oxford Institute for Energy Studies, 24-9.

El-Katiri, L. (2013a). 'Egypt's Energy Trap', Egypt Oil and Gas Newspaper, August 2013.

El-Katiri, L. (2013b). 'Energy Sustainability in the Gulf: The Why and the How', OIES Research Paper, MEP4, Oxford Institute for Energy Studies, March 2013.

El-Katiri, L. (2013c). 'The East Mediterranean: The Middle East's Final Gas Frontier', Oxford Energy Forum, No.93, August 2013.

El-Katiri, L. (2013d). 'The Guardian State and its Economic Development Model', Journal of Development Studies, 26 November 2013. 
El-Katiri, L. (2014 forthcoming). 'Energy Poverty in the Middle East', in: A. Halff, J. Rozhon, and B.K. Sovacool (eds.), Global Energy Poverty: The Silent Crisis, Oxford: Oxford University Press.

El-Katiri, L., Fattouh, B., and Segal, P. (2011). 'Anatomy of an Oil-Based Welfare State: Rent Distribution in Kuwait', Kuwait Programme on Development, Governance and Globalisation in the Gulf States, London School of Economics. Available online at http://www2.Ise.ac.uk/government/research/resgroups/kuwait/documents/Fattouh.pdf (retrieved November 2013).

Energy Charter Secretariat (2010). Jordan: Regular Review of Energy Efficiency Policies 2010, Brussels: Energy Charter Secretariat.

Energy Intelligence Finance (2011). 'Saudi Alternative Energy Plans Face Subsidies Hurdle', Energy Intelligence Finance, 4 May 2011.

Ernst \& Young, Fraunhofer ISI, and World Bank (2010). MENA Assessment of the Local Manufacturing Potential for Concentrated Solar Power (CSP) Projects. Available online at https://docs.google.com/file/d/OB2recxHj7XBvYIZFSkNzRXpRWIE/edit?usp=sharing (retrieved November 2013).

Ernst and Young, ESIA and Eversheds (2013). Developing Renewable Energy Projects. A Guide to Achieving Success in the Middle East. Retrieved from www.mesia.com/wpcontent/uploads/Developing\%20Renewable\%20Energy\%20Projects\%20\%20MENA\%20Guide\%202013.pdf. (accessed July 2013).

ESIA (2012). Sunrise in the Desert. Solar Becomes Commercially Viable in the MENA. Emirates Solar Industry Association.

European Environment Agency (2001). Renewable energies: success stories, European Environment Agency Environmental issue report No 27.

EU/R\&L (2010). Identification Mission for the Mediterranean Solar Plan. Final Report, European Union and Resources and Logistics. Available online at http://ec.europa.eu/energy/international/international cooperation/doc/2010 01 solar plan rep ort.pdf (retrieved November 2013).

EurActive (2013). 'Desertec abandons Sahara solar power export dream', EurActive, 31 May 2013.

Fattouh, B. and El-Katiri, L. (2012a). 'Energy Subsidies in the Arab World', Arab Human Development Report Research Paper Series, United Nations Development Programme. Available at www.undp.org/content/dam/undp/library/Environment\%20and\%20Energy/UNDP-EE-AHDREnergy-Subsidies-2012-Final.pdf (retrieved January 2014).

Fattouh, B. and El-Katiri, L. (2012b). 'Energy and Arab Economic Development' Arab Human Development Report Research Paper Series, United Nations Development Programme. Available at www.arab-hdr.org/publications/other/ahdrps/ENGFattouhKatiriV2.pdf (retrieved January 2014).

Fattouh, B. and El-Katiri, L. (2013). 'Energy Subsidies in the Middle East and North Africa', Energy Strategy Reviews 2:1, June 2013, 108-15.

Fattouh, B. and El-Katiri, L. (2014 forthcoming). 'Saudi Arabia's Emerging Power Sector Predicament', OIES Research Paper, Oxford: Oxford Institute for Energy Studies.

Frankfurt School of Finance and Management (2013). Global Trends in Renewable Energy Investment 2013. Available online at http://fs-unep-centre.org/publications/global-trendsrenewable-energy-investment-2013 (retrieved October 2013).

Guillaume, D., Zytek, R., and Farzin, M.R. (2011). 'Iran-The Chronicles of the Subsidy Reform', IMF Working Paper, WP/11/167, International Monetary Fund.

Hafner, M., Tagliapietra, S., and El Andaloussi, E.H. (2012). Outlook for Electricity and Renewable Energy in Southern and Eastern Mediterranean Countries, MEDPRO Technical Report No. 16/October 2012. Available online at www.medpro-foresight.eu (retrieved July 2013).

Himri, Y. (2009). 'Review and use of the Algerian renewable energy for sustainable development', Renewable and Sustainable Energy Reviews 13, 1584-91. 
Hoffmann, W. (2006). 'PV solar electricity industry: Market growth and perspective', Solar Energy Materials and Solar Cells, 90, 3285-311.

IEA (2010). World Energy Outlook 2010, Paris: International Energy Agency.

IEA (2011a). Deploying Renewables. Best and Future Policy Practice, Paris: OECD/IEA.

IEA (2011b). Harnessing Variable Renewables. A Guide to the Balancing Challenge, Paris Cedeux: International Energy Agency.

IEA (2011c). Solar Energy Perspectives, Paris Cedeux: International Energy Agency.

IEA (2012a). Renewable Energy Technologies. Solar Energy Perspectives, Paris: International Energy Agency.

IEA (2012b). World Energy Outlook 2012,Paris Cedeux: International Energy Agency.

IEA/Ministerio de Minas e Energia/ Governo Federal Brazil (2012). 'Technology Roadmap Hydropower', Paris: International Energy Agency.

IEA, UNDP, UNIDO (2010). Energy Poverty: How to make modern energy access universal?, Special early excerpt from the World Energy Outlook 2010 for the UN General Assembly on the UN Millennium Development Goals. Available at: http://www.worldenergyoutlook.org/media/weowebsite/2010/weo2010 poverty.pdf (retrieved November 2013).

IEA, OPEC, OECD, and World Bank (2010). Analysis of the Scope of Energy Subsidies and Suggestions for the G-20 Initiative, Joint Report Prepared for submission to the G-20 Summit Meeting Toronto (Canada), June 2010.

ILO (2008). 'Employment and labour market implications of climate change', GB.303/ESP/4, Geneva, November 2008.

IMF (2011). Morocco: 2011 Article IV Consultation-Staff Report; Public Information Notice on the Executive Board Discussion; and Statement by the Executive Director for Morocco, IMF Country Report No. 11/341, December 2011.

International Oil Daily (2012). 'Occidental Accelerates Spending on Shah Sour Gas Project', International Oil Daily, 27 July 2012.

IRENA (2012). Renewable Power Generation Costs. Summary for Policy Makers, International Renewable Energy Agency. Available online at www.irena.org/DocumentDownloads/Publications/Renewable Power Generation Costs.pdf (retrieved October 2013).

IRENA (2013a). 'Doubling the Global Share of Renewable Energy A Roadmap to 2030', Working Paper, International Renewable Energy Agency.

IRENA (2013b). Morocco Wind Atlas 2013, IRENA Case Study, available online at http://www.irena.org/globalatlas/Case\%20studies/IRENA Case Morocco/IRENA Case Moroc co.pdf (retrieved October 2013).

IRENA (2013c). 'Renewable Energy Innovation Policy: Success Criteria and Strategies', IRENA Working Paper, March 2013.

Israeli Public Utility Authority website, available at http://www.pua.gov.il/11-he/homepage.aspx (data retrieved October 2013).

Jablonski, S., Tarhini, M., Touati, M., Gonzalez Garcia, D., and Alario, J. (2012). 'The Mediterranean Solar Plan: Project proposals for renewable energy in the Mediterranean Partner Countries region', Energy Policy, 44 (2012) 291-300.

JADWA Investment (2011). 'Saudi Arabia's coming oil and fiscal challenge', July 2011, Riyadh: Jadwa Investment.

Jochem, E., and Gruber, E. (2007). Local Learning-Networks on Energy Efficiency in IndustrySuccessful Initiative in Germany, Amsterdam: Elsevier.

Joint Organisations Data Initiative (JODI, 2013). online database, available at www.jodidata.org/database/access-database.aspx (accessed May, August and September 2013). 
Karakosta, C. and Psarras, J. (2013). 'Understanding CDM potential in the Mediterranean basin: A country assessment of Egypt and Morocco', Energy Policy, 60 827-39, September.

Karekezi, S. (2002). 'Renewables in Africa - meeting the energy needs of the poor', Energy Policy, 30 1059-69.

Kazem, H.A. and Chaichan M.T. (2012). 'Status and future prospects of renewable energy in Iraq', Renewable and Sustainable Energy Reviews, 16 (2012) 6007-12.

Knott, D. (2013). 'MENA Power Sector Preparing For Renewables Push', Middle East Economic Survey, 56:4, 25 January 2013.

Krane, J. (2013). 'Renewable Energy: Hype and Reality', Aspenia International, No. 59-60, 2013, 849.

Kumetat, D. (2012). Managing the Transition: An Analysis of Renewable Energy Policies in ResourceRich Arab States with a Comparative Focus on the United Arab Emirates and Algeria, Unpublished $\mathrm{PhD}$ thesis, available online at http://etheses.Ise.ac.uk/623/1/Kumetat Managing transition.pdf(retrieved November 2013).

Lahn, G. and Stevens, P. (2011). Burning Oil to Keep Cool. The Hidden Energy Crisis in Saudi Arabia, The Royal Institute of International Affairs, Chatham House, December 2011. Available online at www.chathamhouse.org/sites/default/files/public/Research/Energy, \%20Environment\%20and\% 20Development/1211pr lahn stevens.pdf (retrieved Sugust 2013).

Lazard (2009). Levelized Cost of Energy Analysis - Version 3.0. Available online at http://efile.mpsc.state.mi.us/efile/docs/15996/0145.pdf (retrieved October 2013).

Luciani, G. (2010). 'GCC Industrial Exports and the Controversy Over Domestic Energy and Feedstock Pricing', in: Evenett, S.J. (ed.) Will Stabilisation Limit Protectionism? The 4th GTA Report. A Focus on the Gulf Region, London: Centre for Economic Policy Research.

Lund, P.D. (2009). 'Effects of energy policies on industry expansion in renewable energy', Renewable Energy, 34, 53-64.

Luomi, M. (2012). The Gulf Monarchies and Climate Change. Abu Dhabi and Qatar in an Era of Natural Unsustainability, London: C Hurst \& Co Publishers Ltd.

Marktanner, M. and Salman, L. (2011). 'Economic and geopolitical dimensions of renewable vs. nuclear energy in North Africa', Energy Policy, 39 (2011) 4479-89.

Martinot, E., Chaurey, A., Lew, D., Moreira, J.R., and Wamukonya, N. (2002). 'Renewable Energy Markets in Developing Countries', Annual Review of Energy and the Environment 27, 309-48.

MEES (2012). 'MENA Pushing Solar As Climate Change Talks Start In Doha', Middle East Economic Survey, 55:49, 30 November 2012.

MEES (2013a). 'Record Saudi Earnings Boost 2013 Budget Expenditure', Middle East Economic Survey, 56:1, 4 January 2013.

MEES (2013b). 'Aramco Eyes Seven-Well Red Sea Drilling Drive', Middle East Economic Survey, 56:2, 11 January 2013.

MEES (2013c). 'Aramco Gets Green Light To Enter Power Market', Middle East Economic Survey 56:12, 22 March 2013.

MENAREC 4 (2007). Damascus Declaration On the Role of Renewable Energy and Energy Efficiency for the future EU-MENA Cooperation Conclusions and Recommendations from the Middle East and North Africa Conference, Fourth Middle East and North Africa Renewable Energy Conference. Damascus, 21-24 June 2007. Available online at www.escwa.un.org/divisions/div editor/Download.asp?table name=divisions other\&field nam e=ID\&FileID=953 (retrieved October 2013).

Mills, R. (2013). 'Why local sourcing of solar components is economically inefficient', The National, 29 September 2013.

Mizuno, E. (2010). Renewable Energy Technology Innovation and Commercialisation Analysis, Report prepared for the IEA Renewable Energy Division, Cambridge Centre for Energy Studies 
(CCES), Judge Business School, University of Cambridge, Cambridge.

Moner-Girona, M., Ghanadan, R., Jacobson, A., and Kammen, D.M. (2006). 'Decreasing PV costs in Africa: Opportunities for Rural Electrification using Solar PV in Sub-Saharan Africa', Refocus 7, 40-5.

Müller, S., Brown, A., and Ölz, S. (2011). Renewable Energy. Policy Considerations for Deploying Renewables, Paris Cedeux: International Energy Agency.

NEA/IEA/OECD (2005). 'Projected Costs of Generating Electricity', OECD/IEA, Paris, France.

OECD (2011). Towards Green Growth, (Organisation for Economic Co-operation and Development), OECD, Paris, www.oecd.org/dataoecd/37/34/48224539.pdf (retrieved November 2013).

OECD (2013). Renewable Energies in the Middle East and North Africa: Policies to Support Private Investment, OECD Publishing, 66-7.

Ölz, S., Sims, R., and Kirchner, N. (2007). Contribution of Renewables to Energy Security. IEA Information Paper, Paris Cedeux: International Energy Agency/OECD.

Patlitzianas, K.D., Doukas, H., and Psarras, J. (2006). 'Enhancing renewable energy in the Arab States of the Gulf: Constraints \& efforts', Energy Policy, 34 3719-26.

Pejat, N. et al. (2013). 'Iran's achievements in renewable energy during fourth development program in comparison with global trend', Renewable and Sustainable Energy Reviews, 22 (2013) 56170.

Philibert, F. (2011). 'Interaction of Policies for Renewable Energy and Climate Change', Working Paper, International Energy Agency.

Platts (2012). 'Saudi Arabia warns domestic oil use growing at "frightening level" ', Platts, 26 November 2012.

POST (2006). 'Carbon Footprint of Electricity Generation', Postnote N. 268, UK Parliamentary Office of Science and Technology www.parliament.uk/documents/post/postpn268.pdf (retrieved July 2013).

Raspaud, L. (2012). 'Sustainable energy and the fight against poverty', Field Actions Science Reports [Online], Special Issue 6, 2012.

Razavi, H. (2012). Clean Energy Development in Egypt, Tunis-Belvedere: African Development Bank.

Reddy, A.K.N. (1991). Barriers to Improvements in Energy Efficiency, Bengaluru, India: Indian Institute of Science, Department of Management Studies.

REN21 (2011). Renewables 2011. Global Status Report, Paris: REN21 Secretariat.

REN21/ISEP (2013). Global Renewable Futures Report 2013. Available online at www.ren21.net (retrieved November 2013).

REN21/MOFA/IRENA (2013). MENA Renewables Status Report, Paris: REN21. Available online at www.ren21.net/Portals/0/documents/activities/Regional\%20Reports/MENA 2013 lowres.pdf (retrieved November 2013).

Reuters (2013). 'Dubai utility DEWA plans coal-fueled power plant', Reuters, 20 August 2013.

Robinson, D. (2013). 'Living with Intermittent Renewable Power: Challenges for Spain and the EU', Oxford Energy Comment, Oxford Institute for Energy Studies.

Rogner, H.H. and Shihan-Eldin, A. (2013). 'Nuclear Power Option' ch. 4 in Arab Environment 6, 'Sustainable Energy: Prospects, Challenges, Opportunities', Arab Forum for Environment and Development. Available at www.afedonline.org/Report2013/english.html (retrieved November 2013)

Saudi Arabia Solar Industry Association (2013). Sleeping Giant or Mirage? The Potential of PV in and for Saudi Arabia. Available online at http://saudi-sia.com/wpcontent/uploads/2013/09/the potential pv fo ksa2.pdf (retrieved December 2013).

Saudi Gazette (2013). 'KSA, Egypt sign \$1.6b deal to link power grids', Saudi Gazette, 2 June 2013.

Singh, P.P. and Singh, S. (2010). 'Realistic generation cost of solar photovoltaic electricity', Renewable Energy 35, 563-9. 
Solomon, S., Qin, D., Manning, M., Chen, Z., Marquis, M., Averyt, K.B., Tignor M., and Miller H.L. (2007, eds.). Contribution of Working Group I to the Fourth Assessment Report of the Intergovernmental Panel on Climate Change, 2007, Cambridge, United Kingdom and New York, NY, USA: Cambridge University Press.

Stambouli, A.B. (2011). 'Algerian renewable energy assessment: The challenge of sustainability', Energy Policy, 39 (2011) 4507-19.

Supersbergera, N. and Fuehrer, L. (2011). 'Integration of renewable energies and nuclear power into North African Energy Systems: An analysis of energy import and export effects', Energy Policy, 39 (2011) 4458-65.

Tabatabai, H. (2011). 'The Basic Income Road to Reforming Iran's Price Subsidies', Basic Income Studies, 6:1.

Tavanir website, available at http://www.tavanir.org.ir (data retrieved September 2013).

The Guardian (2013). 'The world's largest concentrated solar power plant - big picture', The Guardian, 18 March 2013.

The Jordan Investment Board (JIB). Jordan: Building a Green Economy Tapping into Natural Advantages and Developing Clean Technologies, Economic and Commerce Bureau, Embassy of Jordan, U.S.

Timilsina, G.R., Kurdgelashvili, L., and Narbel, P.A. (2011). 'A Review of Solar Energy Markets, Economics and Policies', Policy Research Working Paper 5845, The World Bank Development Research Group, World Bank.

Trieba, F., Mueller-Steinhagena, H., and Kern, J. (2012). 'Financing concentrating solar power in the Middle East and North Africa - Subsidy or investment?', Energy Policy, 39 (2011) 307-17.

Ummel, K. and Wheeler, D. (2008). 'Desert Power: The Economics of Solar and Thermal Electricity for Europe, North Africa, and the Middle East', Center for Global Development, Working Paper 156, December 2008, www.cgdev.org/files/1417884 file Desert Power FINAL WEB.pdf (retrieved December 2013).

UN (2011). Resolution 65/151. International Year of Sustainable Energy for All, Resolution adopted by the General Assembly on the report of the Second Committee (A/65/436 and Corr.1), General Assembly of the United Nations. Available online at www.un.org/ga/search/view doc.asp?symbol=A/RES/65/151 (retrieved December 2013).

UNEP (2008). Green Jobs: Towards Decent Work in a Sustainable, Low-Carbon World, United Nations Environment Programme, Nairobi.

UNEP RIS $\varnothing$ Centre (2013). CDM projects by host region. Available at www.cdmpipeline.org/cdmprojects-region.htm (accessed November 2013).

UNIDO (2011). Industrial Development Report 2011. Industrial energy efficiency for sustainable wealth creation, United Nations Industrial Development Organization.

van der Zwaan, B., Cameron, L., and Kober, T. (2013). 'Potential for renewable energy jobs in the Middle East', Energy Policy, 60 298-304, September. Available at http://dx.doi.org/10.1016/i.enpol.2013.05.014 (retrieved November 2013).

Vidican, G. (2012). Building Domestic Capabilities in Renewable Energy A case study of Egypt, Bonn: German Development Institute (DIE), 98.

Walz, R., Helfrich, N., and Enzmann A. (2009). 'A System Dynamics Approach for Modelling a LeadMarket-Based Export Potential', Working Paper: Sustainability and Innovation, No. S 3/2009, Fraunhofer Institute for Systems and Innovation Research (Fh-ISI), Karlsruhe, http://econstor.eu/bitstream/10419/28522/1/610704931.pdf.

Wang, X., Kurdgelashvili, L., Byrne, J., and Barnett, A. (2011). 'The value of module efficiency in lowering the levelized cost of energy of photovoltaic systems', Renewable and Sustainable Energy Reviews, 15, 4248-54.

WCED (1987). Our Common Future, World Commission on Environment and Development, Oxford University Press, Oxford. 
World Bank (2005). Household Energy Supply and Use in Yemen, Volume I, Main Report, No. 315/05, December 2005.

World Bank (2008). The Welfare Impact of Rural Electrification. A Reassessment of Costs and Benefits, An IEG Impact Evaluation. Washington D.C.: World Bank. Available online at http://web.worldbank.org/WBSITE/EXTERNAL/EXTOED/EXTRURELECT/0,,contentMDK:2160 3520 menuPK:4489096 pagePK:64829573 piPK:64829550 theSitePK:4489015,00.html (retrieved December 2013).

World Bank (2013a). World Development Indicators database. Available online at http://data.worldbank.org/data-catalog/world-development-indicators.

World Bank (2013b). Enterprise Surveys. Available online at www.enterprisesurveys.org.

World Bank/ESMAP (2011). Middle East and North Africa Region Assessment of the Local Manufacturing Potential for Concentrated Solar Power (CSP) Projects, Fraunhofer Institute for Systems and Innovation Research ISI. Available at www.isi.fraunhofer.de/isi-en/e/projekte/cspmanufacturing $314978 \mathrm{mr}$.php (retrieved July 2013).

Yergin, D. (2006). 'Ensuring Energy Security', Foreign Affairs, 85:2, 69-82.

Zweibel, K. (2010). 'Should solar photovoltaics be deployed sooner because of long operating life at low, predictable cost?', Energy Policy, 38, 7519-30. 


\section{Appendix I: Basic Considerations when Estimating the Cost of Renewable Energy in the MENA}

A large number of country- and regionally-based studies suggest that the potential for solar power and, in some cases, wind power in the MENA region is very high and favourable, in comparison with other main markets such as Europe, and North America. ${ }^{117}$ Below, we discuss some of the factors that complicate the precise estimation of RES costs in the MENA region - suggesting that more research will be required on a country-level in order to solidify this paper's conclusions.

\section{High initial capital costs}

With some variation by RES technology, most renewable energy technologies tend to share a relatively high initial capital cost in comparison with competing energy technologies such as oil- and gas-fired power generation technologies. This basic feature implies two policy-relevant conclusions: first, that renewable energy costs need to be compared on a lifecycle basis rather than based on their initial capital cost, as frequently applied in the case of fossil fuels; second, the financing of renewable energy projects requires specialized financial products.

\section{Comparison of costs on a lifecycle basis}

Lifecycle costs include (in addition to the initial capital cost), factors such the fuel type's capacity factor, the cost of equity, and the cost of debt, operating costs, and expected fuel costs for a given technology. It is typically measured through the Levelized Cost of Energy (LCOE), which can be calculated mathematically using, typically, the following cost elements: ${ }^{118}$

Where $\mathrm{C}_{\mathrm{el}}=$ cost of electricity;

$$
C_{e l}=\frac{I n v^{*} F C R+O \& M+F}{E_{y r}}
$$

Inv = investment cost;

$\mathrm{FCR}=$ fixed charge rate as function of interest rate and economic lifetime (annuity);

$\mathrm{O} \& \mathrm{M}=$ annual cost of operation and maintenance, personnel, insurance, etc.;

$\mathrm{F}=$ annual fuel expenses;

$E_{\text {year }}=$ electricity generated per year $=$ installed capacity $(M W){ }^{*}$ full load hours $(\mathrm{h} / \mathrm{y})^{119}$

Estimating the LCOE for different technologies is a complex and imperfect way of quantifying energy costs, and is additionally vulnerable to changes in local assumptions, such as fluctuating fuel costs for comparable conventional fuel technologies and the cost of debt under changing policy frameworks. Renewable and conventional fuels also differ significantly in the weight of these different factors for their final cost profile:

- $\quad$ the LCOE for renewables is overwhelmingly dominated by initial capital costs, the costs of equity and of debt (fuel costs for most renewable energy technologies being zero, as the sun and wind do not charge for usage);

- $\quad$ the LCOE for conventional fuels is much more determined by eventual long-term fuel costs, and hence assumptions used to estimate these fuel costs.

117 DLR (2005); OECD (2013); IRENA (2013b). Separate studies are available for a variety of MENA countries, including Egypt, Morocco, Algeria, Iraq, Iran, and Saudi Arabia. See Karakosta and Psarras (2013); Stambouli (2011); Vidican (2012); Razavi (2012); Pejat et al. (2013); Dehghan (2011); Kazem and Chaichan (2012); Al-Saleh et al. (2008); Saudi Arabia Solar Industry Association (2013).

118 Useful references for recent, more elaborate work on LCOE calculation methods and/or analysis include NEA/IEA/OECD (2005); Singh and Singh (2010); Zweibel (2010); Branker et al. (2011); Darling et al. (2011); Wang et al. (2011); BNEF (2011). $119 \operatorname{DLR}(2005,126)$. 
LCOE also does not distinguish between high-value 'dispatchable' power that can be provided to match demand, and 'intermittent' power that varies according to climatic conditions.

There are many factors which suggest that standard estimations of the LCOE significantly underestimate the value of renewable energy, including in the Middle East context. One of them is the inherent standard assumption that renewable technology costs differ by technology, but not in usage by country and location. The country-specific value of renewable energy can be significantly higher than that used in standard assumptions; it can include features relating to the underlying capacity factor of a typical power plant, the coincidence of peak-time demand and supply via renewables, and the ability of local electricity tariffs to reflect this difference in value adequately. In other words, LCOE estimates assume perfect markets in terms of:

- locational value,

- $\quad$ the value of a given technology in replacing exportable energy alternatives (such as crude oil) being fully priced into final consumer prices,

- $\quad$ tariffs that are dynamic and adequately reflect peak- versus base-load times,

- $\quad$ knowledge of real production costs across all energy providers.

This is evidently not the case, particularly not in developing economies that are characterized by highly administered energy markets.

One of the resulting caveats in most cost comparisons is that many initial cost estimates for renewable technologies are actually based on European and North American markets, where locational factors such as resource availability, land costs, credit availability, and costs for comparable energy sources, differ tremendously from those present in, for instance, the Middle East and North Africa. The case of solar energy is particularly significant; data from 2005 and 2013 reveals that many MENA economies, particularly parts of the Arabian Peninsula and North Africa, compare favourably to many Southern European neighbours in a number of criteria, including the intensity, duration, and predictability of sunshine throughout the year, suggesting the LCOE for solar technologies should similarly compare favourably to those already deployed in countries such as Spain, Italy, and Greece. $^{120}$

Fuel cost comparisons are also subject to very specific national circumstances, including the size of the grid and the part played by a particular fuel input within the power system. A recent ESIA study based on the GCC economies hints at the likely cost advantage and disadvantage of renewable energy vis-à-vis nuclear power in the wider MENA context. ESIA suggests that:

Nuclear power is likely to be cost-competitive with conventional thermal power at gas prices around $\$ 12 /$ MMBtu $(\sim 70 / \mathrm{bbl}$ oil), cheaper than solar power in most cases. However, if nuclear capacity exceeds $\sim 40 \%$ of peak load, some of it will have to run as intermediate load (not baseload) at lower utilisation factors, significantly increasing the delivered cost of electricity due to the high capital cost of these plants. Smaller markets (e.g. Jordan, Bahrain) will find it difficult to accommodate a single reactor which might represent $30 \%$ or more of total generating capacity. ${ }^{121}$

In other words, renewables will struggle to compete on a cost basis with nuclear power in larger MENA markets, but may prove to be a commercially more likely option for small-scale markets in the absence of regional electricity trade. Whether such tentative cost calculations are eventually relevant for policymakers is a separate question; for while ESIA, a private industry association, sees renewable and nuclear power as primarily complementary sources of energy, ${ }^{122}$ other empirical 
studies suggest the adoption of nuclear energy targets tends to crowd out renewable energy sources for a variety of economic and political reasons. ${ }^{123}$ The effective initial capital cost of nuclear power in comparison with renewable energy is notably much higher, as are wider potential transaction costs (for the acquisition of the politically charged technology compared with widely available renewable energy technology). Nevertheless, the determined plans of several MENA countries to adopt nuclear power clearly signal the lack of consideration given to the up-front capital cost, where political interests support the introduction of a technology, irrespective of its economic cost/benefit potential.

The particular features of renewable energy, mainly its intermittency, further complicate its economics significantly. The economic performance of a utility-level power plant depends to a certain degree on its capacity factor, the percentage of time at which it actually produces electricity. This aspect is even more important where initial investment costs, as in the case of RES technologies, are high. Baseload plants, used to generate off-peak electricity supply throughout the day, offer particularly high value for money on paper, due to their high capacity factor and the large number of hours for which they operate per year. Because many renewable energy sources provide an intermittent energy supply (supply that is interrupted by the absence of certain climatic factors such as sunshine or wind) they only operate for a certain number of hours per day, thereby reducing their capacity factor and hence their primary economic value.

Solar technology illustrates another 'irregularity' of many MENA markets. As previously noted, many renewable energy sources provide an intermittent energy supply - they therefore tend to be used to provide baseload power. However, in MENA economies such as the GCC states, the expected production curve of solar power fits in very well with peak demand for electricity in the afternoon hours in summer, when air conditioning use in the high-income economies of the region leads to surging electricity demand. ${ }^{124}$

While this coincidence of peak electricity demand, and supply of solar power, in the GCC is not perfect (demand continues to peak in the evening hours after sunset), solar energy would be well suited to replace some existing oil- and gas-fired power during the peak-afternoon hours, thereby arguably generating additional value by reducing the use of more valuable fossil fuels. This equation is more true for oil than for natural gas, and indeed where natural gas is produced domestically at relatively low cost, the economics may shift back in favour of gas-fired power generation (we discuss this case below). Not all MENA countries have the option of using natural gas, however, and therefore primarily burn valuable oil. Few MENA economies adequately differentiate price-wise between standard and peak times when pricing their electricity, or else the difference is marginal and rarely reflected in public policymaking. In this case, the higher value of peak-supplying solar technologies is not reflected in official pricing, discriminating against solar power. ${ }^{125}$

Estimates of local LCOE for different renewable technologies are, moreover, highly static, and therefore principally inadequate indicators of a highly fluid industry with high learning curves for technologies such as wind and solar PV, and hence substantial potential for falling costs over the medium term, once initial investment has been made. Modelling under the Mediterranean Solar Plan (MSP) for example, shows that wind power generation costs in North Africa could fall below their alternative fuel competitors by 2020 , whilst solar PV could reach prices close to those of alternative fossil fuels. ${ }^{126}$ Widely used LCOE estimates for different renewable energy technologies - such as those generated by the IEA, REN21, and IRENA - hence differ significantly, and can only provide a

\footnotetext{
123 Marktanner and Salman (2011).

124 Solar power generation tends to peak around midday and in the afternoon, when solar irradiation is at its highest. In the Gulf countries in particular, power demand rises alongside temperatures (and hence solar irradiation intensity), mainly in response to heightened use of air conditioning. Power demand in these countries peaks during summer, and in the early to late afternoon hours. Peak demand continues until the late evening, when conventional solar PV stops producing, so solar coverage is not perfect, but it fits well with local demand patterns up until the evening. Concentrated Solar Power (CSP) circumvents this shortcoming by offering electricity storage capacity in order to continue supplying peak demand after sunset. $125 \operatorname{DLR}(2005,117-19)$.

126 Jablonski et al $(2012,296)$
} 
somewhat indicative picture for costs that are, in reality, highly vulnerable to changing assumptions made on a national basis.

LCOE estimates may also inadequately reflect the locational value of renewable energy sources for off-grid use (which are typical in rural electrification programmes). Studies from different regional contexts (including the MENA countries of Morocco, Yemen, and Jordan) have provided case-based evidence that remote areas can often be cost-effectively provided with basic electricity access via renewable energy technologies, particularly those using home-based solar PV systems. The cost for these technologies often compares favourably to conventional alternatives, such as diesel-based generators, while also contributing significantly to the quality of life and rural health in communities formerly lacking electricity access or using dirty biomass or expensive, dangerous, and polluting kerosene in the home. ${ }^{127}$ Rural use of solar-based systems can also help empower local communities, by offering them an independent energy source and a technology that can, typically, also be maintained locally. ${ }^{128}$ The Emirates-based ESIA notably concludes, in one of its reports on the case of PV, that:

Solar PV is not justifiable on purely economic grounds in countries with access to moderately-priced gas.

However, it can be economic in niche markets (e.g. off-grid or remote areas), and for countries, which despite

sufficient gas resources, are unable to supply demand. ${ }^{129}$

LCOE estimates do not adequately reflect these cost benefits, nor do they provide an incentive for developing countries to consider renewables-based rural electrification programmes - these initiatives have followed international incentives by institutions such as World Bank, which have promoted the concept using specific financial incentives. ${ }^{130}$

\section{Need for specialized financial products}

The high initial capital cost of renewables technologies implies that the financing of renewable energy projects requires specialized financial products, and is often connected with overall higher costs of equity and debt given the initial front-loaded cost structure of these projects, together with unfamiliarity and perceived risk. New renewables deployers are hence often 'punished' twice through technology costs and through the cost of debt - both of which are often higher than in developed, industrialized countries with existing markets for renewable energy technologies. The intermittency of supply of many renewable energy sources also affects the weight of initial capital costs within renewables-based projects in their credit rating. Beck and Martinot explain this difficulty in the following way:

Even though lower fuel and operating costs may make renewable energy cost-competitive on a life-cycle basis, higher initial capital costs can mean that renewable energy provides less installed capacity per initial dollar invested than conventional energy. Thus, renewable energy investments generally require higher amounts of financing for the same capacity. Depending on the circumstances, capital markets may demand a premium in lending rates for financing renewable energy projects because more capital is being risked upfront than in conventional energy projects. ${ }^{131}$

Specific financial products should therefore be designed to take into account the issues involved in decisions concerning the installation of renewable technology.

\section{Difficulty of credit access}

Access to capital in order to finance new renewables projects is critical to enable the technology's uptake. Creditors demand collateral or may offer loan conditions which are not suitable to the lifecycle

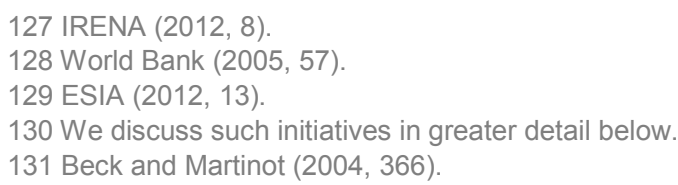


requirements of renewables investment, or may impose high risk premiums owing to the high share in initial capital costs and the variable energy output of many renewable technologies. ${ }^{132}$ Difficulty of access to credit is a near-universal problem throughout the MENA countries, but it is most distinct in North Africa and the Levant, where incomes are significantly lower than in the wealthy Gulf states and where household incomes are, at best, at middle-income level. Egypt illustrates this difficulty:

Egypt is struggling with planning future solar power plants. On the one hand the country is recognized by the international community as a major source of solar energy that could be tapped for domestic use as well as possible export to Europe. On the other hand, the investment cost of solar power plants is presently very high in comparison with the oil and gas plants. The higher cost of solar as well as the tight cash flow of the power sector deter an ambitious plan for development of solar electricity. ${ }^{133}$

For small clients, such as rural households or even urban middle class home investors, microcredits covering the costs for small-scale renewables applications such as rooftop installations may not exist at all; non-transparent banking systems, lacking financial products suited to the financing of renewables projects, render the initial investment in a rooftop installation unaffordable to many. This failure also slows down private company research and development activity. Part of this problem has been the absence of government attention paid to making credit more accessible to both households and commercial entities for such activities.

\section{Transaction costs}

Renewables also entail a whole range of other associated costs, the costs associated with acquiring, understanding, and deploying new technology, known as transaction costs. Transaction costs can be regarded as:

- $\quad$ the investment in time and knowledge - or the willingness and ability to acquire this knowledge - on the producers' side,

- $\quad$ the added time spent on financing new projects given the market's unfamiliarity with the technology and its performance, or

- $\quad$ purely economic, for instance in the form of higher credit costs.

The perceived risk of a technology is directly related to how, and at what costs of capital, projects are financed. On one hand, gas-fired technologies, for instance, are particularly sensitive to fuel prices and price volatility (since fuel costs constitute the majority of generation costs). In contrast, capitalintensive renewables, such as $\mathrm{PV}$, are more sensitive to electricity prices, risk adjusted interest rates, maintenance costs, and insolation levels - the first three of which will be impacted also by the degree to which technology integration costs arise from various 'additional investments' made to stabilize power supply under a rising share of variable power sources. ${ }^{134}$ The cost of loans to fund such 'highrisk' technologies can accordingly be higher than that for conventional power projects on a kWh-basis.

Transaction costs may also be associated with the general acquisition of technological know-how, both at national and at individual company level. While financial means may be available for the initial investment, long-term costs involve the training and education of staff, which may in part account for the poor uptake of RES by the private sector in many developing countries, irrespective of the financial attractiveness of some technologies. The MENA region's traditional focus on fossil fuels, and on other 'indigenous' industries such as agriculture and textiles, has given the region no competitive advantage in technology development for renewables. The case of Israel in the field of solar technology may, in this context, mark an important and highly illustrative exception of a MENA country where a combination of various factors (politically driven interest in energy self-sufficiency, regionally 
unparalleled access to financing, and a skilled and entrepreneurial population) has provided the country with a vastly superior technology position in the renewables segment vis-à-vis the entire Arab world.

Transaction costs can also be political, in the case of politicians' time spent on acquiring information, rallying (and potentially losing) political support by key industrial interest groups, in addition to the sheer complexity of the task for policymakers. Drawing on the parallel case of nuclear energy helps illustrate this point; in the nuclear case, politicians typically invest into extensive diplomatic and financial efforts over years, in order to acquire nuclear technology from partner countries. Renewable energy is considerably less sensitive to geopolitical considerations than nuclear power, but is often more difficult to promote among the local population and to 'sell' to local industries. The promotion and incentivization of 'green' economic concepts require highly focused policy efforts, and they carry less political reputational value than, in many cases, nuclear power. Renewable energy may hence be seen as carrying considerably less political currency domestically, whereas the primary transaction cost for nuclear power on the political level lies abroad.

\section{Integrating intermittent energy}

Another source of costs relates to the integration of technologies delivering intermittent energy supplied into existing grids. ${ }^{135}$ While technically manageable, the integration of intermittent energy supply into a power system requires skill, planning, and political will, and raises very real economic costs. The majority of these costs are sunk costs, to be carried by the investor or the grid operator, which may further lower the expectation of later returns. Many developing countries' utility sectors realistically struggle with RES projects on a larger scale, as these involve a systematic response to energy intermittency. The costs, in the form of investment in additional alternative systems that work with each other to balance out intermittency in a single source (such as investment in wind projects in a variety of places, or the installation of several different technologies in parallel), exceed the perceived economic benefit of renewables over the medium-term in many cases; while technological expertise, often lacking entirely in countries that have relied for decades on fossil fuel technologies, is difficult and requires additional expenditure to obtain.

Research across different economies shows that industrial users may even be willing to pay a premium for what they perceive as stable energy supplies, rather than to engage in potentially costly 'experiments' with renewable power; ${ }^{136}$ while for policymakers in countries with already aging transmission and distribution infrastructure, the prospect of a worst-case scenario in which intermittent renewables destabilize the system and cause additional power outages can be seen as highly problematic.

\section{Positive and negative externalities: costs unaccounted for}

The wide range of benefits associated with renewable energy that are frequently not considered when assessing their respective economic value also form part of the wider picture of distorted costcompetition between renewable conventional sources of energy in the MENA region. We call these costs and benefits positive externalities, in other words, the non-monetary value associated with one or the other technology. One such positive externality is the ability to store electricity in certain technologies, most importantly Concentrated Solar Power (CSP). ${ }^{137}$ The actual value of different energy inputs into an energy system, in reality, depends on the system's ability to value different input sources dynamically. ${ }^{138}$ Dispatchable power is particularly valuable, due to an electricity system's need to be balanced upon fluctuating demand. Flexible oil- and gas-fired power plants hence hold important value as reliable, secure energy providers, but the same value applies also to highly flexible hydro-power, as well as CSP with storage, and to some other renewable technologies such as wasteto-energy plants, all of which require very short periods of time to dispatch power on demand. Other

\footnotetext{
135 See fn 35 .

136 UNIDO $(2011,91)$

137 Not an externality in a properly priced electricity system - thanks to Robin Mills for the note.

138 Bazilian and Roques (2008, 10-11).
} 
technologies, such as solar PV, are variable but their output is highly predictable (electric energy is generated during the hours of daylight), and in many cases this fits well with the demand curve, particularly in the GCC economies. ${ }^{139}$ The LCOE for renewable technologies such as CSP does not reflect this economic value.

The key challenge, as described by Bazilian et al., lies in:

... establishing the underlying place of different technologies within the power dispatch curve, and in the differing ways in which the resulting economics flow through into wholesale and retail electricity prices' ${ }^{140}$

Dynamic fuel tariffs that reflect the value of incremental power production at peak times would allow for a more realistic market valuation of renewables inputs. Anecdotal evidence demonstrates the value even of variable renewable energy sources such as PV - California's 2009 San Diego-based solar system has been shown to lower the cost of electricity for ratepayers over a conventional plant to supply the city's peak demand. ${ }^{141}$ However, such pricing mechanisms within the utility industry are widely absent in the power markets of both the MENA region and many developing economies.

Cost estimates for renewables also exclude a whole range of associated positive externalities, or social benefits, particularly those relating to local technology development, job creation, and the environment. Many of the MENA region's large oil producers have seen how their associated downstream activities, and the use of their oil and natural gas resources (fostering domestic energyintensive industries), have worked in favour of local job creation. However, no such value has been attached to renewable energy technologies, despite their advantage over fossil fuels in areas such as skilled job creation and the greater labour-intensity of these industries vis-à-vis traditional downstream activities, such as refining and petrochemicals. Local self-generation adds further value to many renewables technologies, reducing transmission and infrastructure wear-and-tear and upgrade costs for larger regional grids, where renewables feed into local village-, town- ,or industry-based grids. The economic value of renewables under their best local use is likely to exceed its face value measured on a $\$ / \mathrm{kW}$ basis. ${ }^{142}$

Similarly, RES avoid many of the negative externalities associated with technologies such as fossil fuel and nuclear; these include environmental pollution, the local health impact of home-use of dieseland kerosene-based appliances, the damaging effects of acid rain, declining fishery stocks, and also the wider problems of climate change. ${ }^{143}$ In the case of alternative nuclear power, negative externalities include security risks in case of technical disaster, the disposal cost of nuclear waste, and the risk of nuclear contamination. ${ }^{144}$ None of these costs are adequately reflected in the price of conventional fossil fuels and electricity prices - but because variability, unlike pollution, is a cost paid directly and rather visibly by the utility and/or consumers, it is variability which can be seen as a main barrier to the adoption of renewables, irrespective of their reflection in renewables costs estimates.

The externality problem means that costs and benefits surrounding renewables cannot adequately be captured in 'hard currency', implying that many of the benefits of renewables become a non-tangible luxury that only countries with high income levels, and hence access to capital, can afford to consider. ${ }^{145}$ The MENA region has suffered from this conflict of measurement, as have other developing regions; more than half of MENA economies are middle-income economies, including Morocco, Tunisia, Egypt, Syria, Lebanon, and Jordan. Yemen barely scratches the borderline from low- to lower-middle income countries under the World Bank's classification, and all of these above

139 Bazilian and Roques (2008, 10-11); For a discussion of solar in the North African context, see IEA (2011c, 55-6); Gulf states: ESIA (2012); Egypt: Razavi (2012).

140 Bazilian and Roques $(2008,10)$.

141 Ahn and Arce (2009).

142 Beck and Martinot $(2004,367)$.

143 Beck and Martinot $(2004,367)$. Offshore wind technologies have been associated with environmental issues, which require

a separate, detailed discussion that would move beyond the scope of this paper.

144 EEA $(2001,29)$

145 IEA (2011a, 73). 
face endemic crises relating to public debt and foreign currency reserves. Changing economics of technologies such as PV and wind have, since the early 2000s, nevertheless meant that the traditional argument against renewable energy in developing countries as a 'luxury' source of energy holds trues less and less - a factor that may also account in part for the gradual uptake of the technology at larger scale, not only in parts of the MENA region, but also in other developing economies. 


\section{Appendix II: Renewable Technologies and their Application in the MENA}

\begin{tabular}{|c|c|c|c|c|}
\hline Technology & Features & $\begin{array}{l}\text { MENA Resource } \\
\text { Potential }\end{array}$ & Cost Profile & $\begin{array}{l}\text { Conclusion: Future Role in } \\
\text { MENA Energy Mix }\end{array}$ \\
\hline \multicolumn{5}{|c|}{ High-Potential Renewable Technologies } \\
\hline Solar (PV) & $\begin{array}{l}\text { (+) Abundant and inexhaustible } \\
(+) \text { Proven technology, continued R\&D drive } \\
\text { (+) Short lead times with established policy } \\
\text { support and available finance } \\
(+) \text { High value contributor to off-grid } \\
\text { solutions/rural electrification } \\
(-) \text { Intermittency } \\
\text { (-) Land and water requirement for large PV } \\
\text { installations }\end{array}$ & $\begin{array}{l}\text { High solar radiation } \\
\text { intensity makes MENA } \\
\text { key potential region }\end{array}$ & $\begin{array}{l}\text { Costs falling rapidly, cost-competitive in some } \\
\text { conventional, sun-abundant countries } \\
\text { IEA current cost estimate: US } \$ 110-490 / M W h \text { (ground } \\
\text { mounted); US } \$ 140-690 / M W h \text { (rooftop) } \\
\text { ESIA current cost estimate: US } \$ 154 / M W h \text { (MENA } \\
\text { average) } \\
\text { K.A.CARE current cost estimate: US } \$ 224 / M W h \text { (Saudi } \\
\text { Arabia) }\end{array}$ & $\begin{array}{l}\text { High potential role for MENA } \\
\text { deployment due to high resource } \\
\text { availability and contribution to } \\
\text { energy mix diversification }\end{array}$ \\
\hline Solar (CSP) & $\begin{array}{l}\text { (+) Reliable and medium-mature technology } \\
\text { (+) Electricity storage allows dispatchable } \\
\text { use of electricity generation } \\
\text { (-) Intermittency, depending on storage } \\
\text { facilities } \\
(-) \text { Land requirement } \\
(-) \text { Water requirement }\end{array}$ & $\begin{array}{l}\text { High solar radiation } \\
\text { intensity makes MENA } \\
\text { key potential region } \\
\text { Large-scale deployment } \\
\text { of CSP could render } \\
\text { MENA technology driver } \\
\text { and push costs } \\
\text { downward }\end{array}$ & $\begin{array}{l}\text { Potential for falling costs especially along with scale, yet } \\
\text { slower learning curve means cost gap to PV will } \\
\text { increase } \\
\text { Higher load factor due to storage could render CSP } \\
\text { more price-competitive than PV in individual countries } \\
\text { IEA current cost estimate: US } \$ 180-300 \text { (global); } \\
\text { US } \$ 210 / \mathrm{MWh} \text { (North Africa) } \\
\text { IEA } 2020 \text { projected: }<\text { US } \$ 150 / M W h \text { (North Africa) } \\
\text { K.A.CARE current cost estimate: US } \$ 175 / M W h \text { (Saudi } \\
\text { Arabia) }\end{array}$ & $\begin{array}{l}\text { High potential for role in MENA } \\
\text { deployment, particularly if costs } \\
\text { continue to fall }\end{array}$ \\
\hline
\end{tabular}


Medium-Potential Renewable Technologies

\begin{tabular}{|c|c|c|c|c|}
\hline $\begin{array}{l}\text { Wind } \\
\text { (onshore) }\end{array}$ & $\begin{array}{l}\text { (+) Mature technology } \\
(+) \text { Highly cost-effective at good sites } \\
\text { (-) Intermittency (but capacity factors } \\
\text { increasing due to technology development) } \\
(-) \text { Visual impact }\end{array}$ & $\begin{array}{l}\text { Large wind potential, } \\
\text { particularly in } \\
\text { mountainous and wind- } \\
\text { exposed coastal } \\
\text { regions, especially North } \\
\text { Africa, parts of Mashreq, } \\
\text { Yemen, Oman }\end{array}$ & $\begin{array}{l}\text { Sharp cost reductions since } 1980 \text { s, making onshore } \\
\text { wind cost-competitive in many conventional power } \\
\text { markets } \\
\text { IEA current cost estimate: US } \$ 40-160 / \mathrm{MWh}\end{array}$ & $\begin{array}{l}\text { High potential due to cost } \\
\text { competitiveness in MENA } \\
\text { countries with significant wind } \\
\text { resources }\end{array}$ \\
\hline $\begin{array}{l}\text { Wind } \\
\text { (offshore) }\end{array}$ & $\begin{array}{l}\text { (+) Rapidly developing industry, especially } \\
\text { Europe } \\
\text { (+) Significantly more full-load hours than } \\
\text { onshore } \\
\text { (+) Lesser visual impact than onshore wind } \\
(-) \text { Technology risk } \\
\text { (-) Intermittency } \\
\text { (-) Environmental/marine life impact }\end{array}$ & $\begin{array}{l}\text { Large-scale projects } \\
\text { could render MENA } \\
\text { driver of specialized } \\
\text { R\&D }\end{array}$ & $\begin{array}{l}\text { Significantly higher cost profile due to higher } \\
\text { construction and maintenance costs, higher connection } \\
\text { costs } \\
\text { Very high initial capital requirement } \\
\text { Increasing capital costs since early } 2000 \text { s and expected } \\
\text { to increase further } \\
\text { IEA current cost estimate: US } \$ 100-190 / \mathrm{MWh}\end{array}$ & $\begin{array}{l}\text { Currently still high cost option but } \\
\text { with future potential once } \\
\text { economies compare more } \\
\text { favourably with available } \\
\text { technology alternatives; potential } \\
\text { for large-scale application in } \\
\text { individual markets }\end{array}$ \\
\hline \multicolumn{5}{|c|}{ Other available Renewable Technologies } \\
\hline New Hydro & $\begin{array}{l}\text { (+) Mature technology } \\
(+) \text { Flexible design } \\
\text { (+) Dispatchable where storage facilities } \\
\text { exist - beneficial in combination with greater } \\
\text { contribution of variable RE } \\
\text { (+) Suitable also for local off-grid solutions, } \\
\text { especially remote, rural areas } \\
\text { (-) Negative environmental impact and } \\
\text { public acceptance of large projects }\end{array}$ & $\begin{array}{l}\text { Limited, owing to } \\
\text { existing resource use } \\
\text { where available }\end{array}$ & $\begin{array}{l}\text { Low cost electricity where hydro sources exist } \\
\text { Low maintenance costs } \\
\text { IEA current cost estimate: US } \$ 18-100 / M W h \text { (large); } \\
\text { US } \$ 50-100 / M W h \text { (small \& medium) }\end{array}$ & $\begin{array}{l}\text { Given limited water resources } \\
\text { beyond those countries already } \\
\text { employing hydro, potential mainly } \\
\text { exists for small-scale projects in } \\
\text { unexplored markets. Costs } \\
\text { constitute significant downside risk } \\
\text { to new deployment. }\end{array}$ \\
\hline
\end{tabular}




\begin{tabular}{|c|c|c|c|c|}
\hline Geothermal & $\begin{array}{l}(+) \text { Well-established technology } \\
(+) \text { Dispatchable; suitable for generating } \\
\text { base-load power or year-round supply of } \\
\text { heat (also suitable for cooling) } \\
(-) \text { Heat content not suitable for long- } \\
\text { distance transmission } \\
(-) \text { Environmental impact: air, water, } \\
\text { landscape }\end{array}$ & $\begin{array}{l}\text { Proven geothermal } \\
\text { potential plus (in many } \\
\text { cases) existing } \\
\text { geological knowledge } \\
\text { due to hydrocarbon } \\
\text { production }\end{array}$ & $\begin{array}{l}\text { Costs can be competitive with conventional fossil fuels } \\
\text { where access to high-temperature geothermal resources } \\
\text { exists } \\
\text { IEA current cost estimate: US } \$ 50-80 / M W h \text { (flash, high } \\
\text { temperature); US } \$ 60-200 / M W h \text { (binary) }\end{array}$ & $\begin{array}{l}\text { LT Potential in countries with } \\
\text { geothermal resources but missing } \\
\text { exploration currently hinders } \\
\text { establishment of local advantages }\end{array}$ \\
\hline Wave/Tidal & $\begin{array}{l}\text { (+) Potential due to variable but highly } \\
\text { predictable energy flows; possible benefits in } \\
\text { systems relying on other intermittent sources } \\
\text { of energy such as wind power } \\
(+) \text { Generation capacity large if costs decline } \\
(-) \text { Technology risk/little developed } \\
\text { technology; smaller developments in France, } \\
\text { China, Canada, Russia } \\
\text { (-) Typically small-scale application } \\
\text { (-) Environmental risk }\end{array}$ & $\begin{array}{l}\text { Limited, due to } \\
\text { development stage of } \\
\text { technology } \\
\text { Early and scale-based } \\
\text { deployment could render } \\
\text { region technology/R\&D } \\
\text { driver }\end{array}$ & $\begin{array}{l}\text { High cost technology } \\
\text { IEA current cost estimate: US } \$ 200-350 / M W h\end{array}$ & $\begin{array}{l}\text { Technology at demonstration } \\
\text { phase, future deployment in } \\
\text { MENA with suitable coastal areas } \\
\text { possible; initial (expected) small- } \\
\text { scale application likely to reduce } \\
\text { advantage vis-à-vis technology } \\
\text { alternatives. }\end{array}$ \\
\hline Bioenergy & $\begin{array}{l}\text { (+) Mature technology } \\
\text { (+) Can be cost-competitive with } \\
\text { conventional fuels under right conditions } \\
\text { (+) Dispatchable } \\
(-) \text { Environmental impact, competition with } \\
\text { food and agricultural industries }\end{array}$ & & $\begin{array}{l}\text { Highly site-specific costs; scale, constancy of the heat } \\
\text { load, and the availability and cost of the fuels determine } \\
\text { level of cost-effectiveness } \\
\text { Generally high capital and operation costs compared } \\
\text { with other renewables } \\
\text { IEA current cost estimate: US } \$ 69-50 / M W h \text { (stand } \\
\text { alone); US } \$ 22-67 / M W h \text { (co-firing) }\end{array}$ & $\begin{array}{l}\text { Option to add small-scale power } \\
\text { generation capacity }\end{array}$ \\
\hline
\end{tabular}


Other available Technologies

\begin{tabular}{|c|c|c|c|c|}
\hline Nuclear & $\begin{array}{l}\text { (+) Third generation deployment, globally } \\
\text { used technology } \\
\text { (+) Reliable, non-intermittent base load } \\
\text { supply } \\
\text { (-) Technology/Safety risks } \\
\text { (-) Nuclear waste disposal } \\
\text { (-) Public acceptance } \\
\text { (-) Proliferation risk where nuclear } \\
\text { enrichment is comprised in the programme } \\
\text { (-) LT planning and construction frame } \\
\text { required }\end{array}$ & $\begin{array}{l}\text { Potential for significant } \\
\text { capacity additions (>15\% } \\
\text { of national generation } \\
\text { capacity) in large MENA } \\
\text { power markets to make } \\
\text { use of economies of scale } \\
\text { Potential for regional } \\
\text { supply projects }\end{array}$ & $\begin{array}{l}\text { High initial capital cost but declining marginal cost curve } \\
\text { K.A.CARE current cost estimate: US } \$ 126 / \mathrm{MWh} \text { (Saudi } \\
\text { Arabia) }\end{array}$ & $\begin{array}{l}\text { In practice, national power system } \\
\text { sizes, access to finance, and lack of } \\
\text { local expertise will only render } \\
\text { projects in few countries technically } \\
\text { and economically feasible } \\
\text { Planned in the UAE (2017), KSA } \\
\text { (2020), Jordan, Egypt }\end{array}$ \\
\hline
\end{tabular}

Sources: Author; Brown et al. (2011); CCC (2011); Energy Intelligence Finance (2011); ESIA (2012); IRENA (2012); IEA/Ministerio de Minas e Energia/Governo Federal Brazil (2012); IEA (2012a). 